\title{
Vuorovaikutus, osallistuminen ja tekstin yhteinen tuottaminen
}

\author{
Tapaustutkimus \\ valmennusryhmäkeskusteluista
}

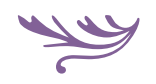

\begin{abstract}
Yksi tapa kasvaa osallistumiseen on tekstin yhteinen tuottaminen kasvokkaisessa vuorovaikutuksessa. Keskustelunanalyysina toteutetussa tapaustutkimuksessa pureudutaan tähän osallisuuteen kasvamisen prosessiin uusiin työkäytänteisiin keskittyvässä henkilöstökoulutuksessa ja työelämään valmentavassa mielenterveyskuntoutuksessa. Tulosten mukaan yhteisöllisiä tekstikäytänteitä on tuettava pedagogisin ratkaisuin.
\end{abstract}

У SOSIAALISESSA TOIMINNASSA mukana oleminen on mielekkään elämän rakennusaines, joka voidaan saavuttaa monin eri tavoin. Joskus se voi edellyttää toimijan omaa aktiivisuutta ja omatoimisuutta, joskus se on etupäässä ulkopuolisten toimijoiden aikaan saamaa. Yhden keskeisen määritelmän mukaan osallistuminen tarkoittaa toimijan tietoisesti ja itsenäisesti harkittua sosiaalisessa toiminnassa mukana olemista siten, että toiminta on hänen omien etujensa ja kiinnostuksensa kohteiden mukaista (Siisiäinen 2010). Tällöin toiminnan alkuun panevana voimana on ennen kaikkea toimija itse, vaikka toimintaa aina jossain määrin ohjaavat myös toimijoiden sisäistämät valtarakenteet (Bourdieu 1977).

Osallistumisesta puhutaan paljon, sillä sen ajatellaan auttavan yhteiskunnan haasteiden kanssa pai- nimisessa (mm. Brodie ym. 2009; Planes-Satorra \& Paunov 2017). Esimerkiksi työntekijöiden aktiivisen osallistumisen työyhteisöä koskeviin muutoksiin tiedetään lisäävän työhyvinvointia ja organisaatioon sitoutumista (mm. Pahkin ym. 2014). Vastaavalla tavalla mielenterveyskuntoutusyhteisöissä toimintaan osallistumisen tiedetään edistävän kuntoutujien hyvinvointia, voimaantumista sekä tyytyväisyyttä ja sitoutumista hoitoon (Corrigan ym. 1999; Hibbard \& Greene 2013).

Artikkelimme näkemyksen mukaisesti osallistuminen on paitsi toimijoista itsestään lähtevää käyttäytymistä (ks. Siisiäinen 2010) myös asia, johon kasvetaan vuorovaikutussuhteissa muiden ihmisten kanssa. Vastavuoroiset ihmissuhteet tekevät mahdolliseksi omaan merkityksellisyyteen ja toiminta- 
mahdollisuuksiin uskomisen, mikä motivoi osallistumiseen (Nivala \& Ryynänen 2013).

Osallistumiseen kasvaminen on näin myös osa sosiaalisaatiota, yhteiskunnan jäseneksi kasvamista, jossa yksilön kasvuprosessia tuetaan ja osallistumiseen ohjataan niin, että hän voi asteittain syvenevän osallistumisen kautta edetä kohti yhteisön täysivaltaista jäsenyyttä (Lave \& Wenger 1991; Nivala \& Ryynänen 2013). Tällaiset ajallisesti pitkätkin kasvuprosessit palautuvat kuitenkin yksittäisiin aikapaikkaisiin tilanteisiin, joissa yksilöt osallistuvat yhteisön toimintaan ja joissa heidän osallistumistaan edistetään eri tavoin luomalla sille mahdollisuuksia ja rajoitteita. Usein osallistumiseen ohjaaminen onkin näkymätöntä, jolloin se on ikään kuin tilanteen muiden, ilmi pantujen tavoitteiden sivutuote.

Näin tapahtuu myös tässä artikkelissa kuvaamissamme konteksteissa, joissa osallistumiseen kasvaminen ei suinkaan ole ääneen lausuttu tavoite. Tutkimme kahden lähiyhteisön valmennusorientoituneita pienryhmäkeskusteluja, joissa tuotetaan erilaisia tekstejä, kuten kirjataan vastauksia ryhmälle annettuihin tehtäviin ja laaditaan ohjetekstejä ja tiedotteita. Katsomme, että näiden varsinaisten tavoitteiden esimerkiksi uusien toimintasuunnitelmien laatimisen - avulla osallistujia kuitenkin kasvatetaan samalla yhteisöllisiin käytänteisiin. Kiinnostuksen kohteenamme onkin juuri vuorovaikutuksessa tapahtuva tekstin yhteinen tuottaminen, jonka hallitsemisen voidaan ajatella olevan yksi tapa parantaa osallistujien mahdollisuuksia osallistua yhteisön toimintaan. Yhtäältä tarkastelemme sitä, miten osallistumista pyritään edistämään tekstin yhteisen tuottamisen avulla. Toisaalta selvitämme tämän tavoitteen toteutumista käytännössä ja kysymme, millaisia osallistumisen mahdollisuuksia ja rajoitteita tekstin avulla osallistaminen faktuaalisesti tuo vuorovaikutukseen.

\section{YHTEISKIRJOITTAMINEN PEDAGOGISENA TEKSTIKÄYTÄNTÖNÄ}

Tekstitaitoihin kiteytyy keskeisiä yhteiskunnallisen osallisuuden ja toimijuuden kysymyksiä (esim. Lehti ym. 2018; NLG 1996). Niitä on tarkasteltu monialaisen tekstitaitotutkimuksen ja erityisesti sen sosiokult- tuurisen lähestymistavan näkökulmasta. Tekstitaidot on tällöin nähty yhteisöllisinä tekstikäytänteinä eli sosiaalisesti ja kulttuurisesti jaettuina tapoina käyttää tekstejä ja kirjoitettua kieltä (Barton 1994; Barton \& Hamilton 2000; Luukka 2009).

Tekstikäytänteet ovat sidoksissa yhteisön muihin toimintakäytänteisiin, ja niihin sosiaalistutaan osallistumalla tekstien ympärillä tapahtuviin yhteisön vuorovaikutustilanteisiin (Barton 1994). Näin uusinnetaan ja pidetään yllä paitsi tekstien käyttötapoja myös niiden ilmentämiä asenteita ja uskomuksia: tekstikäytänteet ovatkin aina sidoksissa laajempiin yhteiskunnallisiin kehityskulkuihin, arvoihin ja normeihin ja siis luonteeltaan ideologisia (Gee 2015; Karvonen 2019).

Tekstitaitojen ja osallisuuden suhdetta käsittelevä tutkimus on kohdistunut erityisesti perusopetukseen, jossa on pidetty keskeisenä opiskelijoiden tarvitseman tekstitaitorepertuaarin laajentamista. Esimerkiksi kirjoittamisen pedagogiikkaan perehtynyt Outi Kallionpää (2017) on tarkastellut kirjoittamista luovaa merkitysten muotoilua korostavassa merkitysyhteiskunnassa, jossa julkinen, yhteisöllinen sisällöntuotanto luo mahdollisuuksia itseilmaisuun, vaikuttamiseen ja osallistumiseen ja on näin keskeinen yhteiskunnallisen osallisuuden ja kansalaisdemokratian osatekijä. Vaikka Kallionpää keskittyykin kirjoittamiseen erityisesti uudessa mediassa, hän pitää tämänkaltaista uutta kirjoittamista osana laajempaa osallisuuden kulttuurin eetosta ja siten tulevaisuuden avaintaitona, jota on syytä kehittää paitsi koulussa myös vaikkapa työpaikoilla, järjestöissä ja kursseilla (Kallionpää 2017, 26-31, 68; ks. myös Jenkins 2016 ym.).

Toistaiseksi on kuitenkin niukasti tietoa tekstitaitojen merkityksestä aikuiskoulutuksen ja työelämän konteksteissa, erityisesti tilanteissa, joita ohjaa osallistumisen ja yhteistoiminnallisuuden ihanne ja joissa yhteisön jäsenyys rakentuu tekstien yhteisen tuottamisen ja muokkaamisen kautta. Tutkimuksemme kohde, tekstin tuottaminen vuorovaikutuksessa, on työelämässä toistuva tekstikäytäntö, jota on tutkittu varsin vähän.

Toisenlaisissa koulutuskonteksteissa, erityisesti yliopistoissa, yhdessä kirjoittamisen pedagogisia etuja on tutkittu paljon. Yhdessä kirjoittamisen on katsottu edistävän syväoppimista, rohkaisevan opiskelijoiden luovuutta ja kriittistä ajattelua sekä auttavan 


\section{KIRJOITTAMISEN}

\section{TUTKIMUKSESSA OLLAAN YHÄ \\ ENEMM ̈̈N KIINNOSTUNEITA}

\section{KIRJOITTAMISESTA}

\author{
PROSESSINA.
}

opiskelijoita työskentelemään jaettujen objektien parissa (Limbu \& Markauskaite 2015, 393).

Yhdessä kirjoittamista on tarkasteltu myös kielenoppimisen näkökulmasta, jolloin sen on havaittu parantavan tuotettujen tekstien kielellistä laatua. Selitykseksi on ehdotettu opiskelijoiden mahdollisuutta vaihtaa ideoita ja antaa toisilleen palautetta (Storch 2005; Dobao 2012; Wigglesworth \& Storch 2012). Yhdessä kirjoittaminen ei kuitenkaan ole suoraviivaisesti yhteydessä ryhmäläisten väliseen lisääntyneeseen yhteistyöhön ja dialogiin. Kasvatustieteilijät Neumann ja McDonough (2015) tarkastelivat yhteiskirjoittamistehtäviä englantia toisena kielenään puhuvien oppilaiden luokassa ja keskittyivät opiskelijoiden yhteisten suunnittelutehtävien ja valmiiden tekstituotosten väliseen suhteeseen. Heidän tuloksensa oli, etteivät kirjoittamista edeltäneet yhteiset keskustelut välttämättä johtaneet parempiin teksteihin kuin mitä syntyi tilanteissa, joissa kirjoittamista ennen ei keskusteltu. Lisäksi osallistujien keskusteluaktiivisuus vaihteli suuresti ryhmittäin.

Yhteiskirjoittamisen tueksi on myös kehitetty pedagogisia malleja. Esimerkiksi Anne Jyrkiäisen ja Kirsi-Liisa Koskinen-Sinisalon (2015) yhteisöllisen kirjoittamisen työtapaan kuuluu kahdeksan toisiinsa limittyvää vaihetta:
1) virittäytyminen työtapaan ja aiheeseen
2) tekstin lukeminen ja tutkiminen
3) kirjoitustehtävän antaminen ja mallintaminen
4) (tekstin) tunnuspiirteiden selventäminen
5) kirjoittaminen pienryhmissä
6) tekstin muokkaaminen
7) esittäminen ja julkaiseminen
8) arviointi.

Vain yksi vaihe on siis varsinaista pienryhmissä kirjoittamista. Työtavassa korostetaankin kirjoittamisen lisäksi tekstien lukemisen, muiden kirjoittajien seuraamisen ja heidän kanssaan toimimisen harjaannuttamista, ja sen keskeinen tavoite on yhteisön puhetapojen omaksuminen. Näin esimerkiksi mallinnusvaiheessa opettajat havainnollistavat oppijoille, miten tekstiä voidaan tuottaa yhteistoimin sen lopputuloksesta keskustellen ja neuvotellen. (Mts. 82-83.)

Tutkimukset vahvistavat siten, että onnistunut yhteiskirjoittaminen on sidoksissa tapaan, jolla koko kirjoitusprosessi on organisoitu mahdollistamaan osallistujien keskinäistä, tekstiin kiinnittyvää vuorovaikutusta. Aiemmissa tutkimuksissa ei ole kuitenkaan tarkasteltu sen tarkemmin eri kirjoitusprosessien vuorovaikutuskäytänteitä ja niiden vaikutusta prosessin etenemiseen ja osallistujien mahdollisuuksiin päättää tekstin muotoilusta.

\section{KIRJOITTAMINEN JA YHTEINEN TEKSTIN TUOTTAMINEN VUOROVAIKUTUKSENA}

Tekstien tuottamisesta yhdessä on oltu kiinnostuneita myös kirjoittamisen tutkimuksessa. Kuten keskusteluntutkijat Mondada ja Svinhufvud (2016) toteavat, kirjoittamisen tutkimuksessa on havaittavissa käänne, jossa ollaan yhä enemmän kiinnostuneita kirjoittamisesta prosessina. Tässä tutkimuksessa nojaudumme erityisesti keskustelunanalyyttiseen traditioon, jossa tarkastellaan kirjoittamista osana kasvokkaisia vuorovaikutustilanteita. Kirjoittaminen nähdään tällöin sosiaalisena, kehollisena toimintana (Komter 2006; Mondada \& Svinhufvud 2016).

Keskustelunanalyytikot ovat kiinnittäneet huomiota siihen, miten monet institutionaaliset dokumenttityypit tuotetaan säännönmukaisesti osana tietynlaisia vuorovaikutustilanteita (ks. esim. Komter 2006; van Charldorp 2014). Aiempi tutkimus on lisäksi tunnistanut tyypillisiä vuorovaikutusjaksoja, joissa kirjoittaminen säännönmukaisesti esiintyy. Esimerkiksi poliisikuulusteluissa (van Charldorp 2014) kirjoittaminen on yleensä poliisin kysymystä ja kuulusteltavan vastausta seuraava kolmas toiminto. Samoin päätöksentekovuorovaikutuksessa kirjoittaminen tyypillisesti seuraa ehdotusta ja sen 
hyväksymistä (esim. Asmuss \& Oshima 2012; Pälli \& Lehtinen 2014; Nissi 2015; Mondada 2016). Tässä tutkimuksessa sen sijaan tarkastelemme sellaisia vuorovaikutustilanteita, joissa yhteinen tekstin tuottaminen on osa kokoontumisen päätarkoitusta. Analyysimme kohdistuu siihen, millaisten vuorovaikutusrakenteiden välityksellä kirjoittaminen tapahtuu. Kiinnitämme myös huomiota siihen, miten osallistujat varmistavat sen, että teksti on muodoltaan ja sisällöltään sopivaa kyseisessä tilanteessa kirjoitettavaksi. Kutsumme tätä tekstin ominaisuutta 'dokumentointikelpoisuudeksi'.

Tekstien dokumenttikelpoisuuden tutkiminen liittyy aiemman tutkimuksen löydökseen, jonka mukaan kirjoittamisen julkisuus voi suuresti vaihdella eri vuorovaikutustilanteissa. Joskus tuotetaan vain muistiinpanoja omaan käyttöön (esim. Svinhufvud 2016), joskus taas osallistujien on tuotettava yhteinen teksti, josta he ovat kollektiivisesti vastuussa (esim. Samra-Fredericks 2010; Asmuss \& Oshima 2012; Nissi 2015; Mondada 2016). Kun ryhmällä on yhteinen vastuu tekstistä, se saatetaan kirjoittaa taululle tai tietokoneen avulla valkokankaalle, jossa se on kaikkien nähtävillä. Osallistujien on tällöin neuvoteltava ja päästävä yksimielisyyteen tekstin muotoilusta. Esimerkiksi Nissi (2015) osoittaa, miten tämä neuvottelu etenee kahdenlaisten ehdotussekvenssien avulla fasilitaattorin vetämässä kokouksessa: ensin kokouksen osallistujat tekevät kirjausehdotuksia, ja sitten fasilitaattori tekee niiden pohjalta ehdotuksia lopullisesta muotoilusta. Hyväksymällä ehdotukset osallistujat sitoutuvat yhteisesti sovittuihin muotoiluihin. Olennaista on lisäksi se, että monissa tilanteissa kirjoitetut dokumentit toimivat tulevaisuuteen suuntautuvina ohjenuorina, esimerkiksi strategisina suunnitelmina, jolloin sitoutumalla kirjoitettavaan tekstiin osallistujat sitoutuvat myös toimimaan tietyllä tavalla. Meidän aineistossamme dokumentointikelpoisuuden varmistaminen valikoitui analyysin kohteeksi, koska se näytti aiheuttavan vuorovaikutuksen osallistujille erityisiä, kirjoittamisen julkista luonnetta koskevia haasteita.

Tarkastelemissamme tapauksissa kirjoittaminen on julkista: niissä pyritään tuottamaan yhteinen teksti, jonka kaikki ryhmän jäsenet voivat hyväksyä, joka julkistetaan kirjoittamisen jälkeen ja joka suuntaa yhteisön tulevaisuuden toimintaa. Osallistujat suuntautuvat tällöin nimenomaan tekstin dokumentointikelpoisuuteen. Aiempi tutkimus on osoittanut (esim. Moore ym. 2010), että dokumentit voivat olla tärkeitä organisaatioiden keskeisten toimintojen järjestymisessä. Kun dokumentit on kerran muotoiltu, niistä tulee organisaatioissa itsenäisiä kokonaisuuksia siinä mielessä, että organisaatioon liittyvillä uusilla jäsenillä ei ole enää pääsyä dokumenttien muotoilua edeltäviin prosesseihin (Nissi 2015, 20; vrt. Pälli ym. 2009 strategiadokumenteista). He kohtaavat näin tekstuaaliset dokumentit nimenomaan dokumentteina. Pohtiessaan tekstiensä dokumentointikelpoisuutta osallistujat ottavat huomioon juuri sen, että tekstistä tulee pysyvä dokumentti, jonka pitää olla sellaisenaan ymmärrettävä ja tarkoituksenmukainen.

Tutkimus on nostanut esiin myös seikkoja, jotka edesauttavat osallistumista tekstien yhteiseen tuottamiseen. Etenkin suuressa ryhmässä oleellista näyttäisi olevan kirjoittamistoiminnan organisoiminen. Esimerkiksi Nissi $(2015,19)$ osoittaa, miten ryhmän jakaminen pienryhmiin mahdollistaa kaikkien osallistumisen, vaikka yhteisessä koko ryhmän keskustelussa yleensä vain pienryhmien sihteereillä on mahdollisuus päästä ääneen. Mikäli keskustelussa on fasilitaattori, hänen roolinsa on olennainen. Mondada $(2016,175)$ osoittaa, miten fasilitaattori reagoi hienovaraisesti yhteisymmärryksen rakentumiseen ja siinä ilmeneviin ongelmiin. Samalla on kuitenkin selvää, että fasilitaattorilla on myös valtaa, koska hän viime kädessä konkreettisesti kirjoittaa tekstin (Nissi 2015, 19).

\section{AINEISTO, MENETELMÄ JA TUTKIMUSKYSYMYKSET}

Aineistomme koostuu videonauhoitetuista vuorovaikutustilanteista kahdessa aikuiskoulutuskontekstissa: 1) uusiin työkäytänteisiin keskittyvässä henkilöstökoulutuksessa (45 tuntia) ja 2) työelämään valmentavassa mielenterveyskuntoutuksessa (19 tuntia) Kontekstit ovat artikkelin tavoitteiden näkökulmasta mielenkiintoisella tavalla sekä samanlaisia että erilaisia. Aineistoja yhdistää yhtäältä se, että niissä kummassakin pyritään lisäämään valmennettavien 
työkykyä, mikä taas edellyttää heidän omaehtoista osallistumistaan toimintaan. Toisaalta niitä yhdistää se, että molemmissa käytetään tekstejä ja kirjoittamista osallistumisen edesauttajana. Erilaisia ne ovat siinä mielessä, että kun henkilöstökoulutuksessa osallistujat ovat työelämässä, kuntoutuskontekstissa toiminnan tavoite on tukea paluuta työelämään. Tarkennamme konteksteja aineiston analyysin yhteydessä.

Aineiston analyysimenetelmänä on keskustelunanalyysi. Se on laadullinen lähestymistapa, joka pohjautuu sosiologian ja etnometodologian piiristä lähtöisin olevaan teoriaan sosiaalisen vuorovaikutuksen organisoitumisesta (Heritage 1984; Schegloff 2007; Stevanovic \& Lindholm 2016). Keskustelunanalyysin tutkimuskohteena ovat vuorovaikutuksen käytänteet, joiden avulla jokapäiväistä sosiaalista elämää rakennetaan.

Keskitymme yhteisöllisten tekstikäytänteiden ja osallistumisen väliseen suhteeseen ja pohdimme tekstin yhteiseen tuottamiseen liittyviä odotuksia, mahdollisuuksia ja rajoitteita. Aineistonäytteiden avulla havainnollistamme aineistossamme usein toistuvia käytäntöjä. Henkilöstökoulutuksesta valitsemamme aineistonäytteet edustavat osallistujien rutiininomaisia tapoja yhtältä organisoida yhteistä kirjoittamista, toisaalta varmistaa kirjausten dokumentointikelpoisuus. Näin tuotettavan tekstin yhteisen omistajuuden säilyttäminen näyttäytyy merkittävänä, joskin voitettavissa olevana haasteena. Mielenterveyskuntoutusaineistossa tekstin yhteistä tuottamista koskevat haasteet ovat vaikeampia. Olemme valinneet näytteet siten, että ne havainnollistaisivat tässä kontekstissa esiintyvien yhteisöllisten tekstikäytänteiden haasteiden kirjoa mahdollisimman laajasti. Aineistonäytteissä esiintyvät henkilöiden nimet on korvattu pseudonyymeillä ja käytetyt erikoismerkit on selitetty (liite 1).

\section{TEKSTIN YHTEINEN TUOTTAMINEN HENKILÖSTÖKOULUTUKSESSA}

Analyysimme tekstin yhteisestä tuottamisesta henkilöstökoulutuksessa osoittaa sen monisyiseksi ja haasteelliseksi toiminnaksi, jossa osallistujat joutuvat sekä organisoimaan oman kirjoittamistoimintansa että varmistamaan tuotetun tekstin toimivuuden julkisena kirjallisena tuotoksena.

Tarkastelemamme henkilöstökoulutus tulee suomalaisen koulutusorganisaation johtoryhmille suunnatusta, lähes vuoden kestäneestä ja organisaation ulkopuolelta ostetusta koulutusohjelmasta, joka tähtäsi osallistavan ja yhteistoiminnallisen organisaatiokulttuurin kehittämiseen. Tilaisuuksissa olivat paikalla koulutuksen tarjoavan yrityksen konsultti, organisaation ylintä johtoa sekä 13-45 johtoryhmää, jossa kussakin on neljästä kuuteen jäsentä (kuva 1).

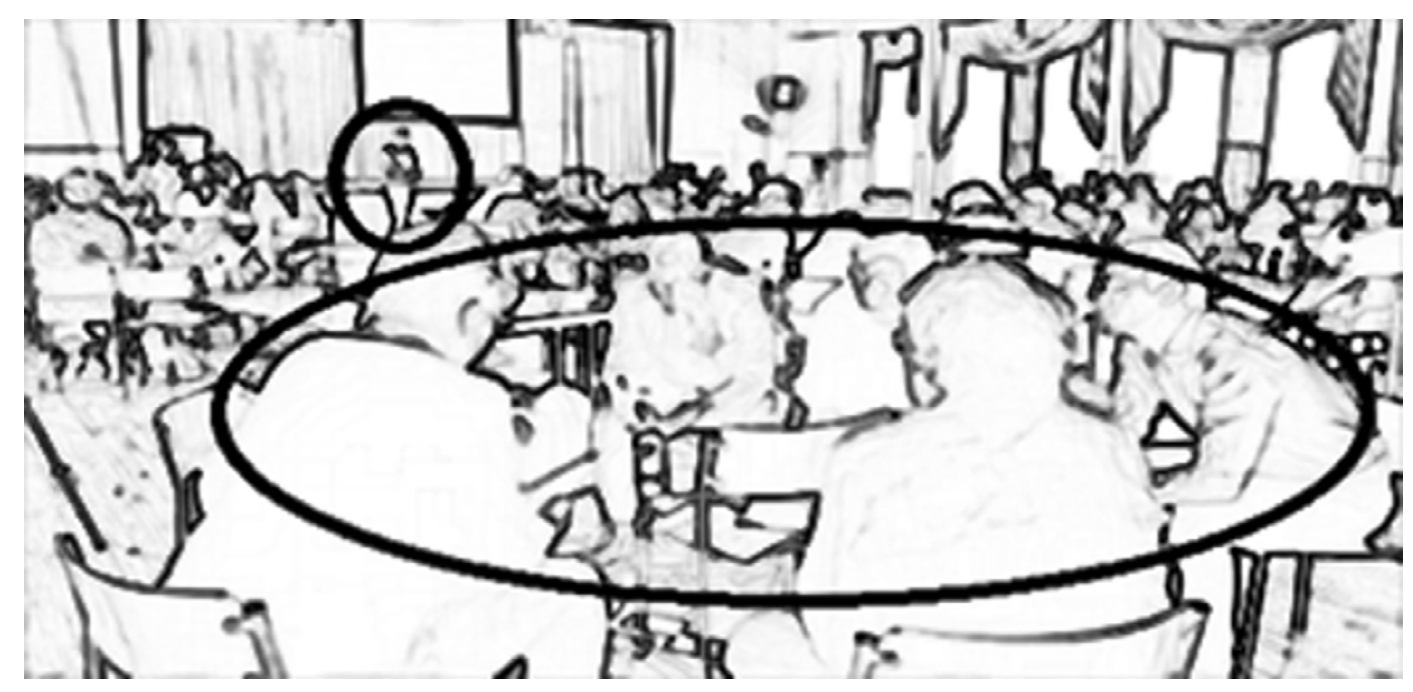

Kuva 1. Henkilöstökoulutustilanne 
Konsultti antaa johtoryhmille heidän työkäytänteitään koskevia refleksiivisiä keskustelutehtäviä. Kirjoittaminen ja tekstin tuottaminen liittyvät näihin olennaisesti, sillä tehtävänantoihin kuuluu usein pyyntö vastata kirjallisesti tai dokumentoida keskustelun ydinsisällöt myös kirjallisessa muodossa. Tämä tapahtuu digitaalisella alustalla, johon kaikilla osallistujilla on pääsy ja joka heijastetaan suurelle valkokankaalle. Johtoryhmissä yksi ryhmän jäsen toimii kulloisenkin kerran kirjurina, joka kirjaa ryhmän puolesta asioita alustalle tablettia käyttäen. Kun ryhmä on saanut keskustelutehtävän tehtyä ja julkaisee sen vastauksen tai muistiinpanot digitaalisella alustalla, tekstit ovat kaikkien osallistujien nähtävissä ja niitä luetaan ja kommentoidaan koko koulutusohjelman ajan. Kirjaukset toimivat näin ryhmien kollektiivisina itseilmauksina, joiden voi katsoa rakentavan ryhmien identiteettiä vertaisten ja esimiesten silmissä ja asemoivan ryhmiä organisaation sisällä.

\section{Kirjoittamistoiminnan organisointi}

Henkilöstökoulutuksessa siirtyminen tekstin yhteiseen tuottamiseen vaatii ryhmiltä monenlaista vuorovaikutuksellista työtä. Koulutus on massatilanne, eikä konsultti ole läsnä jokaisen ryhmän luona, vaan tehtävänannon jälkeen ryhmät etenevät itsenäisesti.
Koska tekstien tuottamista ohjataan vain alkuohjeistuksen verran, ryhmien itsensä päätettäväksi jää, milloin kirjoittamiseen ryhdytään, kuka toimii kirjurina ja mitä keskustelusta kirjataan. Toisin sanoen voidakseen tuottaa tekstiä yhteistoimin ryhmän on organisoitava oma kirjoittamistoimintansa.

Esimerkki 1 havainnollistaa kirjoittamistoiminnan itsenäiseen organisointiin liittyviä haasteita. Konsultti on antanut koulutettaville keskustelutehtävän, joka on sisältänyt pyynnön muodostaa keskustelun keinoin yhteinen näkemys esitettyyn kysymykseen ja kirjata se digitaaliselle alustalle. Ryhmä 1 on ennen katkelmaa puhunut kuitenkin muista asioista annetun tehtävään sijaan. Ryhmässä on neljä jäsentä, joista ketään ei ole vielä valittu kirjuriksi.

Rivillä 4 JÄ1 ehdottaa JÄ2:lle kirjuruutta ja tukee kielellistä ehdotustaan ojentamalla tälle samanaikaisesti tablettia. JÄ2 tuottaa puolestaan ehdotukseen hyväksyvän jälkijäsenen joo voin (rivi 6) ja ottaa hänelle ojennetun esineen vastaan. Ehdotussekvenssi, jonka kuluessa ryhmän kirjuri valitaan, tuotetaan näin multimodaalisesti kielellisin, kehollisin ja materiaalisin keinoin. Ellei kirjuria ole päätetty etukäteen, itse kirjoitusväline onkin luonteeltaan mobiili ja ei-yksilöity, mikä mahdollistaa joustavan kirjurin valinnan. Ennen kuin kirjoitusväline on vakiinnutettu jollekin, kirjuria ei ole päätetty, eikä tekstin tuottaminen voi alkaa.

\section{Esimerkki 1}

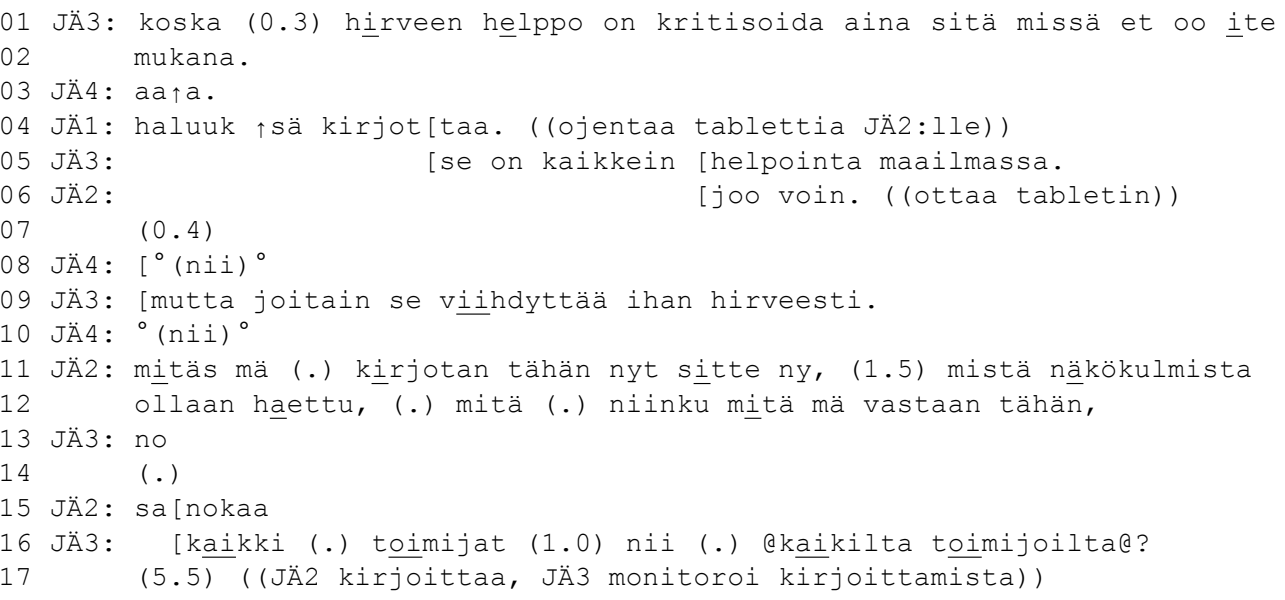


V OIDAKSEEN TUOTTAA

TEKSTÏ̈ YHDESSÄ RYHMÄN

ON ORGANISOITAVA OMA

KIRJOITTAMISTOIMINTANSA.

Katkelmassa ehdotussekvenssi tekee kuitenkin muutakin, sillä sen avulla osallistujat siirtyvät keskustelussa uuteen toimintaan. Ryhmä ei ole vielä suuntautunut konsultin tehtävänantoon, ja erityisesti JÄ3 ja JÄ4 ovat keskustelleet muista aiheista. Ehdotusvuorollaan (rivi 4) JÄ1 rakentaa vuorovaikutuksellisen liittouman Jä2:n kanssa, ja nämä kaksi alkavat viedä toimintaa kohti tehtäväorientoitunutta keskustelua ja sen kirjaamista. Kirjurin ehdottaminen mahdollistaa siis toiminnallisen siirtymän tilanteessa, jossa yksi ryhmän jäsen osoittaa muita suurempaa valmiutta koulutuksen agendan mukaiseen toimintaan - ilman, että hänen tarvitsee ottaa itselleen erityistä toiminnan ohjaajan roolia.

Kirjurin päättäminen ja vakiinnuttaminen tuo keskusteluun kuitenkin uusia haasteita, sillä ryhmän on samanaikaisesti säilytettävä tekstin yhteinen omistajuus. Katkelmassa on nähtävissä, kuinka JÄ2 itse orientoituu tähän tekemällä muille avunpyyntöjä (rivit 11-12) ja suoranaisia kehotuksia (rivi 15) osallistua tekstin tuottamiseen. Näin hän tekee näkyväksi roolinsa kirjurina, ei tekstin varsinaisena tai ainoana omistajana. Samalla hän ohjaa tapaa, jolla toiset voivat vastata esitettyyn pyyntöön upottamalla vuoroonsa tehtävänantoon liittyvän lainauksen mistä näkökulmista ollaan haettu (rivit 11-12) digitaaliselta alustalta. Toistamalla kysymyksen juuri siinä muodossa kuin se on annettu kirjuri varmistaa saavansa toisilta oikeanlaista, kirjaukseen tarvittavaa kielenainesta. Toiset ryhmäläiset orientoituvat puolestaan omaan rooliinsa kirjausmateriaalin ja -aineksen tarjoajina.

Rivillä 16-17JÄ3 vastaa koko ryhmälle suunnattuun kysymykseen muotoillen vuoronsa "saneluksi". Toisin sanoen hän tuottaa sen erityisellä kirjallisella lukuäänellä ja esimerkiksi sijamuodoiltaan JÄ2:n pyyntöön mukautettuna (mistä näkökulmista => kaikilta toimijoilta), mikä mahdollistaa sen, että kirjuri pystyy kirjaamaan vastauksen alustalle reaaliaikaisesti sellaisenaan.

Esimerkissä 1 teksti siis rakentuu ryhmän jäsenten koordinoidussa yhteistoiminnassa osana sekventiaalisesti etenevää keskustelua ja sen puhetoimintoja. Kirjoittamistoiminnan organisointi asettaa läsnäolijat osallistumisen näkökulmasta epäsymmetrisiin asemiin, jolloin tuotettavan tekstin yhteisen omistajuuden säilyttäminen muodostuu keskeiseksi haasteeksi. Henkilöstökoulutusaineistossamme osallistujat onnistuvat kuitenkin yhteisöllisiä tekstikäytänteitä taitavasti hyödyntäen selvittämään tämän haasteen.

\section{Dokumentointikelpoisuuden varmistaminen}

Sen lisäksi, että henkilöstökoulutukseen osallistuvat ryhmät organisoivat kirjoittamistoiminnan ja varmistuvat siitä, että kaikki sitoutuvat kirjoitettuun tekstiin, ryhmillä on myös toisenlainen haaste: niiden on varmistuttava siitä, että teksti on sisällöltään ja muodoltaan dokumentointikelpoista - sellaista, että se huomioi tekstin seuraamuksellisuuden. Dokumenttikelpoisuuteen näyttäisi aineistossamme liittyvän monenlaisia tekstitaitoihin kiinnittyviä seikkoja, eritoten taitoa tunnistaa henkilöstökoulutuksen sosiaaliselle toimintatyypille ja kehittämiskulttuurille ominaisia puhetapoja sekä hyödyntää niiden mukaista kirjoitetun kielen symbolijärjestelmää (vrt. Luukka 2013). Dokumentoitavien sisältöjen tulee olla riittävän yleisellä tasolla, irrallaan organisaatioiden konkreettisista toiminnoista. Kirjausten tulee olla koulutuksessa vallitsevan ideologian mukaisia. Lisäksi niiden tulee olla järkevässä suhteessa muiden ryhmien kirjauksiin, mikä edellyttää ryhmiltä erityisiä, käytettyyn teknologiaan liittyviä julkisuustaitoja (vrt. Kallionpää 2017, 66), kykyä kirjoittaa ryhmän julkisesti asemoivaa ja kategorisoivaa tekstiä. Esimerkki 2 kuvaa, miten osallistujat neuvottelevat keinoista saada kirjauksistaan dokumentointikelpoisia.

Esimerkki 2 on toisesta ryhmästä, jossa sen tehtävänä on valita "prosesseja", joita osallistujat johtoryhmänä kehittävät. Ryhmä on aiemmin valinnut kirjurikseen JÄ1:n. Tässä tilanteessa päädytään kirjaamaan kaksi asiaa, joista keskitymme jälkimmäiseen. Ennen esimerkkiä JÄ2 on nostanut esiin oppiainei- 
den rajat ylittävän "tiimityöskentelyn". JÄ4:n aloitteesta on päädytty siihen, että yleisemmällä tasolla kyse on "OPSin jalkauttamisesta". Esimerkin alussa (rivit 4-5) tämä kirjataan muistiin. Samalla Jä2 kuitenkin jatkaa keskustelua, ja hän näyttäisi palaavan vielä "yhteistyön tekemiseen".

Riveillä 1-3 ja 9-11 JÄ2 kuvailee teemaa, jota hän tarjoaa kirjauksen pohjaksi. Koska JÄ1 hakee vahvistusta ensimmäiselle kirjaukselleen pälllekkäin JÄ2:n vuoron kanssa, osaa vuorosta on vaikea kuulla, mutta hänen ajatuksensa näyttäisi kytkeytyvän "rakenteisiin” (rivi 11).JÄ2:n vuorossa on useita piirteitä, jotka osoittavat, että hän hakee oikeaa muotoilua: se on kysymysmuodossa (ks. miten rivillä 1 ja pystytäänks rivillä 9), hän aloittaa kysymyksensä kahteen kertaan hieman eri muodossa, ja se päättyy epämääräistävään adverbiaaliin jotenki (rivi 11).

JÄ4 tarttuu JÄ2:n esille nostamaan teemaan (rivi 12). Hän luonnehtii omaa ehdotustaan yleisen tason muotoiluksi (rivi 13) ja tuottaa termimäisen substantiivilausekkeen yhteistyön rakenteiden kehittäminen.JÄ3 hyväksyy JÄ4:n ehdotuksen, korostaen nimenomaan sitä, että tämä on löytänyt hyvän muotoilun (se on hyvä sana, rivit 17-18). Kirjuri (JÄ1) osoittaa myös tässä vaiheessa hyväksyvänsä muotoilun jatkamalla kirjoittamista (rivi 14).

Esimerkissä 2 osallistujat siis neuvottelevat sopivasta, dokumentointikelpoisesta muotoilusta. Yksi

\section{Esimerkki 2}

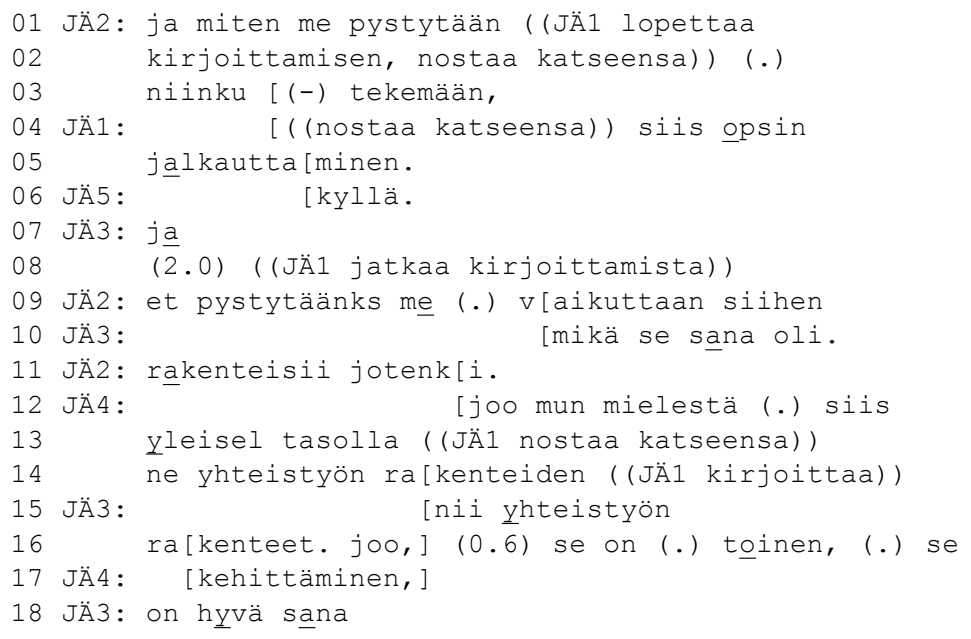

\section{Esimerkki 3}

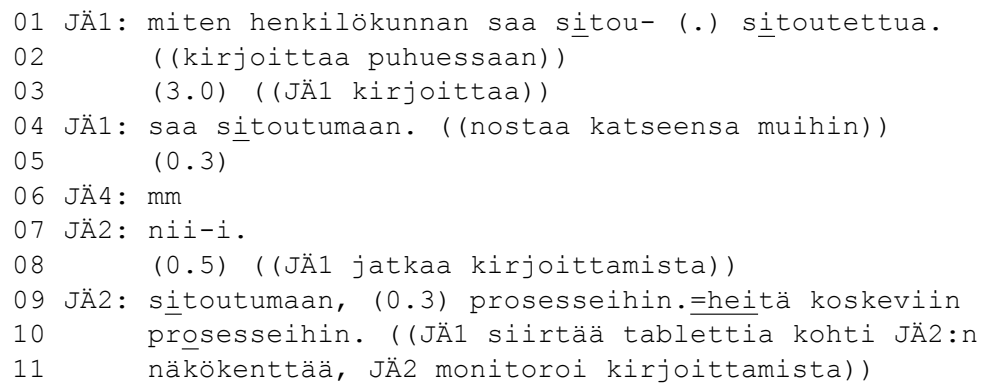


osallistuja ehdottaa riittävän abstraktia, termimäistä muotoilua ja hakee muilta sille hyväksynnän. Kirjoittaminen jatkuu vasta, kun dokumentointikelpoinen muotoilu on löydetty.

Esimerkissä 3 dokumentointikelpoisuus liittyy reflektointitehtävään, jossa osallistujien pitää kirjata kaksi kysymystä, jotka ovat heidän työlleen tällä hetkellä tärkeitä. Ryhmässä on neljä jäsentä. JÄ1 toimii kirjurina.

Esimerkin alussa kirjuri alkaa kirjata ryhmän vastausta tabletille. Samalla hän lukee ääneen kirjaustaan ja tekee sen näin näkyväksi muille. Tällöin muiden on mahdollista puuttua kirjauksen sisältöön, jos he eivät katso voivansa sitoutua siihen. Tosiasiassa kirjattava sisältö kuitenkin nousee varsin suoraan edeltävästä keskustelusta (ei näy esimerkissä).

Kirjaaminen kuitenkin keskeytyy. Rivillä 4 JÄ1 lopettaa kirjoittamisen, nostaa katseensa ja tekee muutosehdotuksen. Hän esittää toisenlaista verbimuotoa. Nostamalla katseensa hän hakee ehdotukselleen vahvistusta muilta, ja myös saa sen. JÄ4 vastaanottaa ehdotuksen melko neutraalilla partikkelilla $\mathrm{mm}$ (rivi 6), mutta JÄ2 sen sijaan tuottaa nii-partikkelin, joka osoittaa selvemmin sitoutumista ehdotukseen. Tällöin JÄ1 jatkaa kirjoittamista, kun taas JÄ2 toistaa ehdotuksen ja jatkaa sitä (rivit 9-10). Lisäksi JÄ1 siirtää tablettia kohtia JÄ2:ta, mikä mahdollistaa sen, että JÄ2 monitoroi kirjoittamista. Dokumentointikelpoinen kirjaus syntyy siis osallistujien yhteistyönä.
Dokumentointikelpoisuus näyttäisi tässä tapauksessa liittyvän siihen, miten kirjaus kytkeytyy meneillään olevan koulutuksen ideologiaan. Kielellisesti muutos on hyvin pieni: verbin vaihtaminen toiseen, lähes samaa tarkoittavaan verbiin. Verbien välillä on kuitenkin sellainen ero, että ne edellyttävät erilaista toimijuutta. Alkuperäinen ehdotus, sitouttaa, konstruoi johdon aktiiviseksi toimijaksi, jonka toiminta kohdistuu sitoutettaviin, henkilökuntaan. Uusi muotoilu, sitoutua, sen sijaan korostaa henkilökunnan omaa toimijuutta. Uusi kirjaus sopii paremmin koulutuksen osallistuvaa johtamista korostavaan eetokseen.

Analyysimme osoittaa, että dokumentointikelpoisen kirjauksen löytäminen on koulutuksen osallistujille käytännöllinen ongelma, jonka ratkaisemiseksi he joutuvat tekemään töitä. Kirjurin on monitoroitava keskustelua, poimittava siitä ehdotuksia ja pääteltävä, missä vaiheessa ehdotukset ovat valmiita dokumentoitavaksi. Tuotettavan tekstin yhteisen omistajuuden säilyttämiseksi kirjurit voivat hakea vahvistusta kirjauksilleen. Toisaalta kirjurin on erityisellä tavalla suuntauduttava tekemiensä kirjausten julkiseen luonteeseen ja sen edellyttämiin vaatimuksiin tuotetun tekstin sisällöstä ja kieliasusta, mikä vahvistaa kirjurin epäsymmetristä osallistuja-asemaa muihin läsnäolijoihin nähden. Toiminnan lopputuotoksen, tekstin, yhteisyys vaatii siten niin kirjurilta kuin muilta läsnäolijoilta yhteisöllisten tekstikäytänteiden hallintaa, jonka avulla epäsymmetriaa voidaan lieventää.

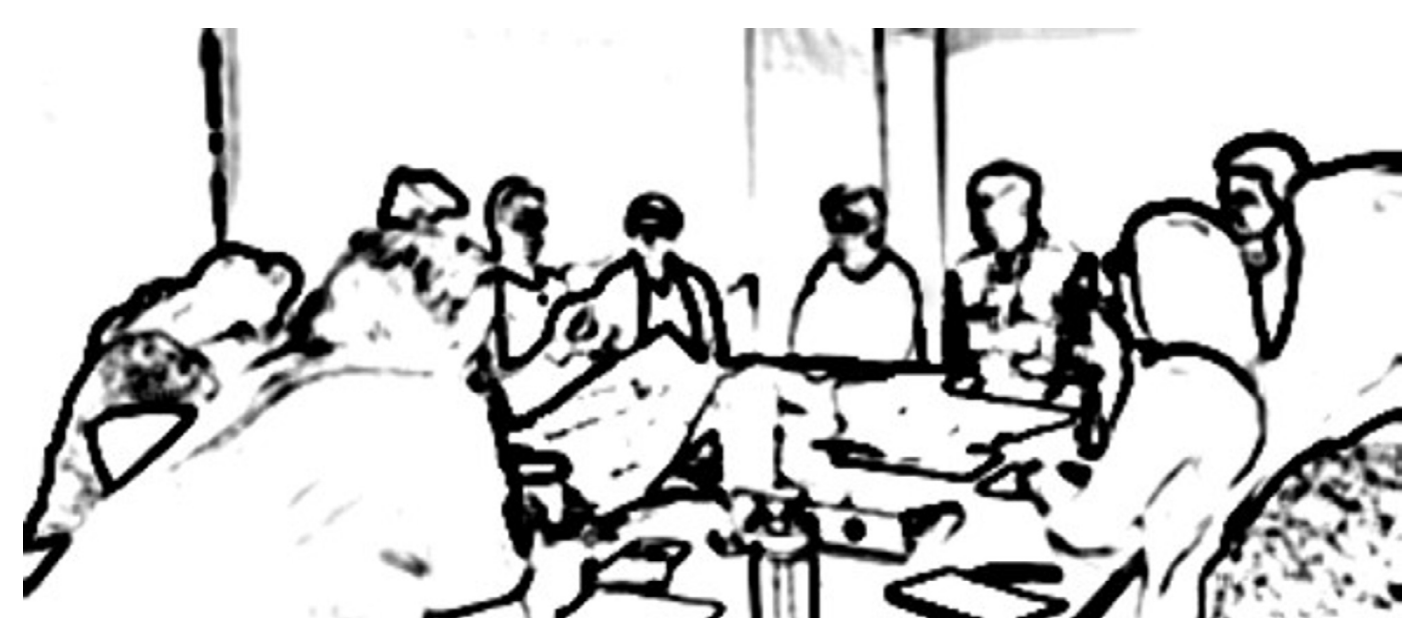

Kuva 2. Työvalmennusryhmän kokoontuminen 


\section{TEKSTIN YHTEINEN TUOTTAMINEN}

\section{MIELENTERVEYSKUNTOUTUKSESSA}

Osallistumisen epäsymmetriat ja haasteet ovat tuttuja henkilöstökoulutuksen esimerkeistä, mutta mielenterveyskuntoutuksen pienryhmäkeskusteluissa niitä koskevat haasteet ovat vieläkin vaikeampia, johtuen monisyisistä tekstikäytänteiden hallinnan ongelmista tässä kontekstissa. Tarkastelemamme mielenterveyskuntoutuksen vuorovaikutustilanteet ovat mielenterveyskuntoutujien Klubitalo-yhteisön jäsenilleen avoimesta työvalmennusryhmästä, jossa keskustellaan ryhmäläisten mahdollisuuksista kehittää työelämätaitojaan ja palata työelämään. Kokoontumisissa on tyypillisesti paikalla yhdestä kahteen työntekijää ja kahdesta kahdeksaan mielenterveyskuntoutujaa.

Tekstin yhteisen tuottamisen näkökulmasta keskeisessä osassa ovat niissä kirjoitettavat pöytäkirjat ja muistio sekä muille yhteisön jäsenille suunnatut tekstit. Kirjurina toimii yleensä yksi ryhmäläinen, työntekijä tai kuntoutuja, joka valitaan tehtäväänsä kunkin kokoontumisen alussa. Teksti kirjoitetaan usein tietokoneella ja heijastetaan valkokankaalle, jolloin kaikilla ryhmäläisillä on pääsy kommentoimaan rakentuvan tekstin yksityiskohtia. Mielenterveyskuntoutuksessa yhteistä tekstiä tuotetaan ohjaajavetoisemmin kuin henkilöstökoulutuksessa, jolloin kirjoitustyön organisoiminen on yleensä ohjaajan vastuulla.

\section{Tekstin yhteisen tuottamisen monimuotoiset haasteet}

Esimerkissä 4 havainnollistamme mielenterveyskuntoutusta koskevassa aineistossamme ilmenevien tekstin yhteiseen tuottamiseen sisältyvien haasteiden monimuotoisuutta. Katkelmassa ryhmäläiset keskustelevat Klubitalo-järjestön omasta siirtymätyöohjelmasta, jonka avulla mielenterveyskuntoutujia pyritään saattamaan työelämään. Ohjelmaan pääsy on kuitenkin rajoitettua. Niinpä ryhmäläiset ovat laatimassa yhteisölleen tiedotetta, jossa kuvataan siirtymätyöohjelmaan hakeutumisen prosessin eri vaiheet ja jolla on siksi yhteisössä tärkeä seuraamuksellinen tehtävä.

Ennen esimerkin alkua yksi kuntoutuja on ehdottanut, että siirtymätyöohjelmaan haluavien tulisi ryhmässä kertoa omasta osaamisestaan ja siitä, miksi haluaisi päästä töihin. Katkelman alussa ohjaaja (rivit 1-3) palaa mainittuun ehdotukseen kutsumalla omasta osaamisesta kertomista "itsen markkinoimiseksi”. Samalla hän kuitenkin hakee ehdotukselle parempaa muotoilua viitaten näin ongelmallisuuteen, joka ilmaukseen markkinoida itseään sisältyy.

Ohjaajan aloitusvuoron jälkeen ryhmän toinen ohjaaja liittyy keskusteluun, minkä myötä ohjaajat yhdessä päätyvät siihen, ettei pelkän motivaation ja kiinnostuksen mainitseminen tekstissä riitä vaan tekstiä olisi jatkettava lauseella, joka alkaisi sanoilla: "Kiinnostuneet kertovat ryhmässä [--]" (rivit 18-20). Siksi on ongelmallista, että seuraavat kuntoutujien (KUN2 \& KUN3) vuorot vain toistavat sitä, minkä on jo todettu olevan osa tekstiä (rivit 11-12) ja mitä näytöllä jo lukee (rivit 22-23). Ohjaajan huomautettua ehdotuksen tarpeettomuudesta (rivit 25-27) toinen kuntoutuja (KUN2) vetoaa näkemisen ongelmaan (rivi 28).

Esimerkin alkupuoli havainnollistaa, kuinka haasteellista keskustelun ja syntyvän tekstin muodostumisen seuraaminen voi olla, mikä tässä kontekstissa heikentää kuntoutujien osuutta tekstin tuottamiseen. Vuorovaikutuksen jatko nostaa esiin muita yhteisöllisten tekstikäytänteiden haasteita.

Esimerkin 4 jatkossa aiemmin vaiti ollut kuntoutuja (KUN3) tuottaa uuden ehdotuksen tekstin muotoilemiseksi. Sisällöllisesti ehdotus on relevantimpi kuin aikaisemmat ehdotukset, sillä se ei toista näytöllä jo näkyvää tekstiä. Ehdotuksessa on kuitenkin kaksi muuta ongelmaa. Ensinnäkin lauseen sisältämien kielioppivirheiden vuoksi (kiinnostuneet kertoo ryhmästä itsestään, rivi 30) ehdotus ei ole dokumentointikelpoinen sellaisenaan. Toiseksi kuntoutuja palaa ehdotuksessaan juuri siihen muotoiluun (markkinoivat itseään, rivi 32), jonka ohjaaja on edellä esittänyt ongelmallisena (ks. alku, rivit 1-3).

Kun ohjaaja (OHJ2) seuraavaksi ottaa vuoron, hän näyttääkin käytännössä "poistavan" kuntoutujan ehdotuksen: hän pyytää tekstiin muotoiluja aivan kuin edellä ei olisi minkäänlaista ehdotusta esitettykään (sanokaas nyt (0.4) mitä tohon laitetaan, rivit 3436). Vastauksena tähän kuntoutuja (KUN3) toistaa ehdotuksensa kieliopillisesti asianmukaisemmassa 
muodossa, edelleen kuitenkin käyttäen ohjaajan näkökulmasta ongelmallista markkinoida itseään -fraasia (rivi 37). Tässä kohdin toinen ohjaajista $(\mathrm{OHJ} 1)$ ottaa tilanteen hallintaansa. Hän tarjoaa tekstin muotoilulle ratkaisun (kertovat ryhmässä itsestään ja miksi minut pitäisi valita, rivi 38), joka rakentuu täydelliseksi jatkoksi hänen työtoverinsa ehdottamalle lauseen aloitukselle ("Kiinnostuneet kertovat ryhmässä [--]", rivit 18-20). Tämä muotoilu päätyykin tekstin lopulliseksi muotoiluksi.

\section{Esimerkki 4 (alku)}

01 OHJ2: sähä Mari ((OHJ1)) sanoit sen kivasti, (0.8) ma-markkinoitava

02 itseään vai mitä, (0.4) miten sä sanoit sen, (.) mukavammin sä

03 sanoit et markkinoida itseään on vähä.

$04 \quad(2.0)$

( (poistettu 6 riviä))

11 OHJ1: mä mietin et riittääks se ku tos lukee toi et käsitellään

12 kiinnostusta motivaatiota ja kuinka varmasti ois valmis

13 tekemään työtä.

$14 \quad(0.8)$

15 OHJ2: nii me voidaan lisätä siihenki vaan.

$16 \quad(1.0)$

17 OHJ1: nii

18 OHJ2: viel jotenki perään että, (0.4) että kiinnostuneet,

19 (4.0) ((OHJ2 kirjoittaa))

20 oHJ2: kertovat, (1.0) ryhmässä.

21 (9.0) ((OHJ2 lopettaa kirjoittamisen, katsoo papereita))

22 KUN2: motivaatiosta (--)

23 KUN3: ja motivaatiosta (.) työhön.

$24 \quad(2.0)$

25 OHJ2: joo? (.) se lukiki siinä jo samassa,

$26 \quad(1.0)$

27 OHJ2: tossa. ((OHJ2 katsoo näyttöä))

28 KUN2: katoku mä en nää tästä. (.) tekstii.

$29 \quad$ (.)

\section{Esimerkki 4 (jatko)}

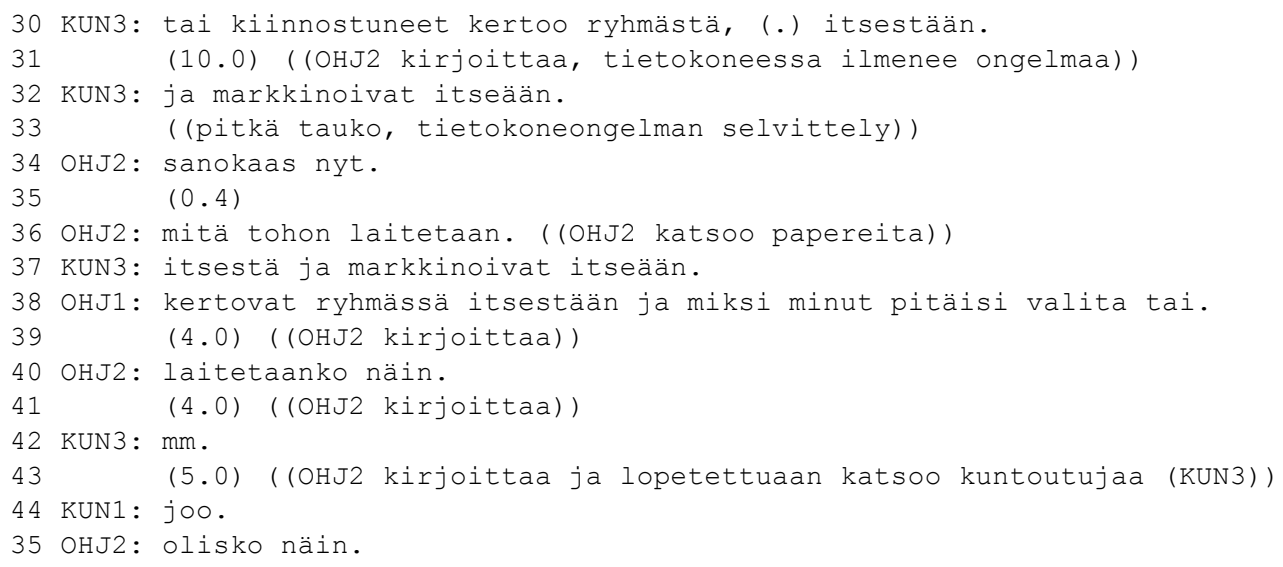


Esimerkki 4 havainnollistaa sitä, kuinka vahvasti ohjaajat toimivat saadakseen tekstin sellaiseksi kuin itse haluavat: he kerta toisensa jälkeen kohtelevat kuntoutujien ehdotuksia riittämättöminä.

Samalla kun ohjaajat kontrolloivat syntyvän tekstin sisältöä ja kielellistä muotoa ja näin pienentävät kuntoutujien osuutta ryhmän yhteisessä lopputuotoksessa, he kuitenkin tekevät myös runsaasti päinvastaista vuorovaikutuksellista työtä ja pyrkivät siten kehystämään tekstin nimenomaan ryhmän yhteiseksi tuotokseksi.

\section{Illuusio yhteisestä tuotoksesta}

Toisin kuin henkilöstökoulutuksessa, mielenterveyskuntoutuksessa tekstien kehystäminen ryhmän yhteiseksi tuotokseksi vaikuttaa illuusion rakentamiselta. Esimerkissä 5 keskustellaan siitä, millaisia valintakriteerejä siirtymätyöhön valittavalle Klubitalon jäsenelle on. Kuntoutuja (KUN1) toimii kirjurina, jonka tehtävänä on kirjoittaa koneella ryhmän päätökset muistiin. Päätökset perustuvat pääasiassa toiselta Klubitalolta saatuun valmiiseen materiaaliin, jota kuntoutuja kopioi suoraan edessään olevasta tulosteesta.

Katkelman alussa (rivi 1) KUN1 kysyy, mitä hä- nen pitäisi kirjoittaa muistiin. Hän itse ei siis suuntaudu valmiiseen materiaaliin kirjoittamisen resurssina. Riviltä 3 alkavassa vastausvuorossaan ohjaaja kuitenkin viittaa valmiiseen materiaaliin, ohjeistaen kuntoutujaa ikään kuin kysymyksessä olisi jo aiemmin annetun kirjoitustehtävän tekeminen (ohjeistuksista luokkahuoneessa ks. Hyytiäinen 2017; pAliitepartikkelista direktiiveissä ks. Stevanovic 2017).

Seuraavaksi KUN1 lukee paperista sen ensimmäistä kohtaa, jota on jo aiemmin käsitelty keskustelussa (rivi 9). Ohjaaja korjaa ja huomauttaa (rivi 14), että hän tarkoitti valmiin materiaalin kakkoskohtaa, joka kuitenkin vaihdetaan tämän Klubitalon dokumentin ensimmäiseksi kohdaksi (rivi 18). Ohjeistamalla kuntoutujaa kyseisessä vaihdoksessa ohjaaja ilmaisee, ettei heidän tarvitse noudattaa toisen Klubitalon laatimaa tekstiä sataprosenttisesti. Voidaankin ajatella, että kohtien muuttaminen on ohjaajan tapa lisätä meneillään olevan toiminnon tarkoituksenmukaisuutta. Sen sijaan, että tapaamisessa ainoastaan kopioitaisiin toisen Klubitalon samaan käyttötarkoitukseen luomaa tekstiä, tekstiä minimaalisesti muokkaamalla lopputuloksesta tulee omaperäisempi.

Esimerkin jatko valottaa, miten neuvottelu työn alla olevasta tekstistä jatkuu.

\section{Esimerkki 5 (alku)}

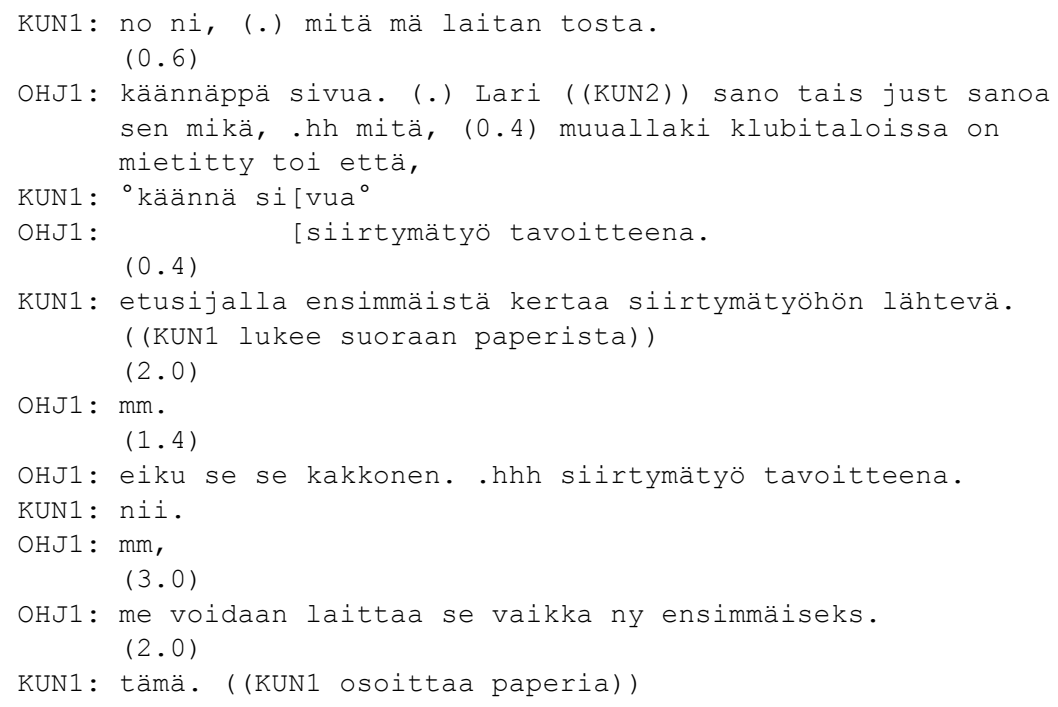




\section{Esimerkki 5 (jatko)}

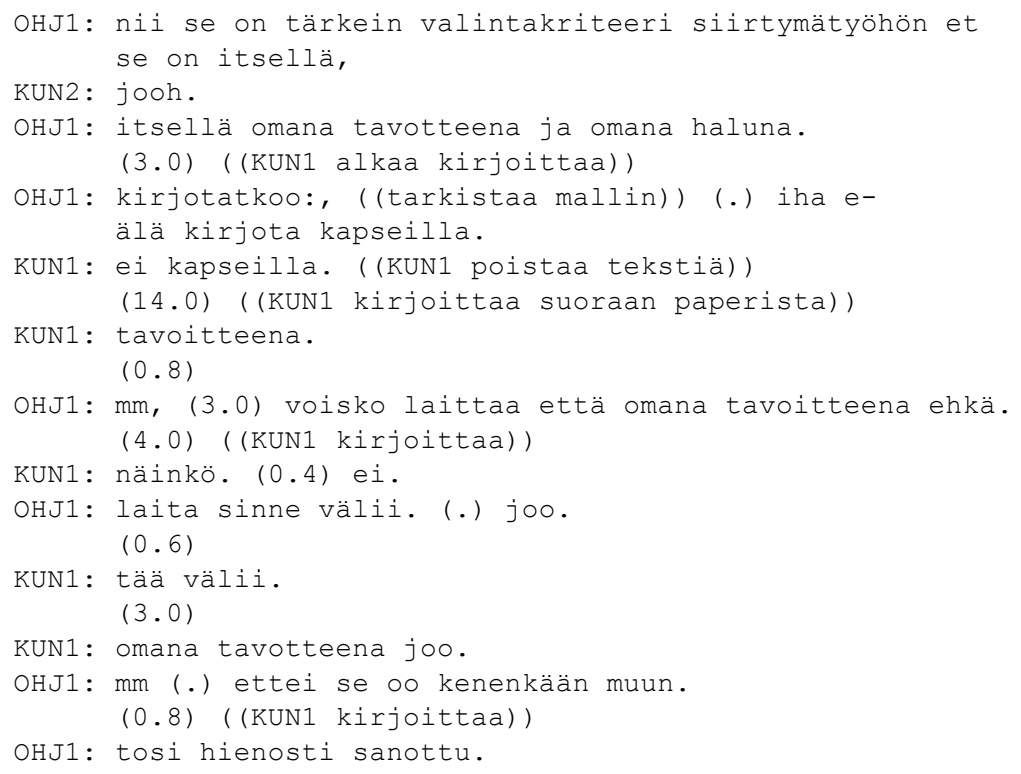

Edellisen katkelman lopussa kuntoutuja esitti tarkistuskysymyksen, joka koski sitä, mitä kohtaa valmiista materiaalista hän laittaisi tekeillä olevan dokumentin ensimmäiseksi kohdaksi. Ohjaaja vastaa (rivit 21-22 ja 24) laajentamalla aihetta "siirtymätyö tavoitteena”, joka on valmiissa dokumentissa esiintyvä muotoilu. Ohjaaja korostaa (rivi 24), että siirtymätyö on omana tavotteena ja omana haluna. Kuntoutuja ryhtyy kirjoittamaan ja ohjaaja antaa tarkat ohjeet käytännön yksityiskohdissa (älä kirjota kapseilla, rivi 27). Ohjeiden jälkeen kuntoutuja kuitenkin kirjoittaa suoraan sen, mitä paperissa lukee (rivi 30) eikä sisällytä muotoiluunsa ohjaajan elaborointia, jossa virkkeeseen lisätään pääsanaa eli "tavoitetta” määrittelevä "omana"-sana.

Ohjaaja toistaa (rivi 32) ehdotuksensa kyseisen sanan lisäämisestä, ja tämän jälkeen (rivit 34-37) ohjaaja ja kuntoutuja yhdessä säätävät sanan sijoittamista valmiiseen lauseeseen. Kun kuntoutuja on kerran muotoillut virkkeen suullisesti onnistuneesti ja osoittanut ymmärtäneensä, mitä ohjaaja haluaa (omana tavoitteena joo, rivi 39), ohjaaja formuloi idean vielä kertaalleen (rivi 40) ja lopuksi kehuu sitä (rivi 42). Ohjaaja siis käytännössä kehuu omaa ehdotustaan. Koska kuntoutuja on kuitenkin kertaalleen onnistunut muotoilemaan ehdotuksen suullisesti (rivi 40) ja kirjoittamaan sen oikein koneella (rivi 41), syntyy illuusio, että tuotos olisi yhteinen ja että kehu olisi kohdistunut kuntoutujalle.

\section{Dokumentointikelpoisuudesta neuvottelu}

Esimerkeissä 4 ja 5 kirjoittamista kehystää pyrkimys tuottaa kieliopillisesti ja tyylillisesti oikein muotoiltua tekstiä siinä hetkessä, jossa tehdään päätöksiä tekstin sisällöstä. Toisinaan kuitenkin kirjoitetun tekstin muokkaaminen erotetaan omaksi, toisessa ajankohdassa tapahtuvaksi toiminnoksi, mitä seuraava esimerkki havainnollistaa. Esimerkissä 6 ohjaaja $(\mathrm{OHJ} 1)$ aloittaa keskustelun siitä, miten varsinainen siirtymätyöntekijän valinta tulisi tehdä (rivit 1 ja 4-5). Kuntoutuja (KUN3) toimii kirjurina ja ehdottaa, että valinta tehtäisiin halukkuuden perusteella (rivi 12).

KUN3 tekee ehdotuksen (rivit 11-12), mutta ei oma-aloitteisesti ryhdy kirjoittamaan asiaa muistiin, 


\section{Esimerkki 6}

01 OHJ1: siirtymätyöntekijän valinta. (.) mitäs siihen hei nyt tota.

$02 \quad(0.4)$

03 KUN1: valinta.

04 OHJ1: niin, (.) mitä te aattelette miten me valitaan meidän

05 siirtymätyöntekijä sitten ku tulee paikka auki.

$06 \quad(0.8)$

07 KUN1: ${ }^{\circ}$ ei mitään tietooh. ${ }^{\circ}$

$08 \quad(1.0)$

09 KUN2: ainaki ryh[mässä (--)

10 OHJ1: [nin miten te ajatte[lette ite (--)

11 KUN3: [no esimerkiksi

12 halukkuuden perusteella [ja sitte joutuu jotenki katsomaan,

3 OHJ1: [no ni.

OHJ1: joo,

15 (2.0) ((KUN3 katsoo OHJ1, laittaa sormet näppäimistölle))

16 OHJ1: ((katse KUN3)) laitetaan (.) laitetaan ihan kaikki mitä tulee

7 mieleen me voidaan sitte poistaa sieltä ja muokkailla jälkikäteen

aina mitä tule i- ikinäkään mieleen ni pistetään ensin vaan tonne

((katse alas)) (.) ei tarvii niinku alkaa tässä sitä perkausta.

(12.0) ((KUN3 kirjoittaa))

KUN1: 'halukkuuden pohjalta ((katsoo näyttöä))

KUN3: 'halukkuuden pohjalta ${ }^{\circ}$

KUN1: pohjalta (.) se on väärin kirjotettu.

$(1.0)$

OHJ1: no emmä tiiä halukkuuteen pohjautuen sanotaan näin.

((poistettu rivejä: KUN3 ja KUN1 vaihtavat ajatuksia sopivasta sanasta. KUN1 hyväksyy sanan "pohjalta". KUN3 kirjoittaa.))

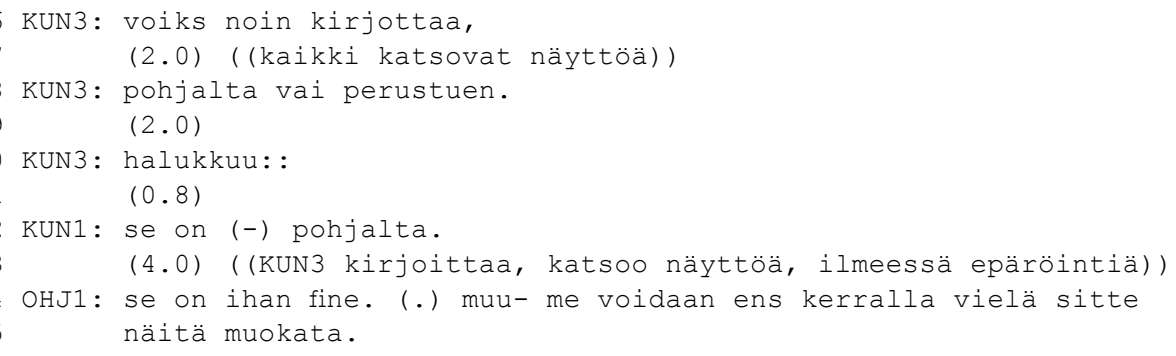

vaan katsoo ohjaajaa (rivi 15). OHJ1 ohjeistaa kirjoittamista (rivit 16-19) toteamalla, ettei tässä hetkessä tehdä valmista tekstiä, vaan että nyt on vain tarkoitus laittaa ideoita yhdessä muistiin. Ohjeistuksen jälkeen KUN3 ryhtyy kirjoittamaan ehdotusta muodossa halukkuuden pohjalta (rivit 20-21) KUN1 tarttuu sanaan pohjalta ja kyseenalaistaa sen käytön (rivi 23). OHJ1:n tuotua esiin (rivi 25), ettei pohjalta-sanassa sinällään ole huomauttamista, seuraa kuntoutujien välinen neuvottelu sopivista sanois- ta. KUN3 ilmaisee edelleen epäröintiä kirjoitusasusta (rivit 26, 28 ja 33). OHJ1 arvioi, että kuntoutujan kirjoittama teksti on riittävä (se on ihan fine, rivi 34) ja määrittelee jälleen muokkaamisen tästä hetkestä erilliseksi toiminnoksi (rivit 34-35).

Esimerkissä 6 kuntoutujat orientoituvat siihen, että tilanteessa tuotettavan tekstin tulisi olla kirjoitusasultaan oikeakielistä jo siinä hetkessä, kun asioita käsitellään. Ohjaaja sen sijaan kannustaa vapaaseen ideointiin ja määrittelee tekstin muokkaamisen 
myöhemmin tehtäväksi toiminnoksi. Toisin kuin esimerkeissä 4 ja 5, esimerkissä 6 ohjaaja toisin sanoen määrittää väljemmät kriteerit dokumentointikelpoisuudelle. Näin hän tukee ryhmän vapaata ideointia hetkessä, jossa takertuminen tekstin muokkaamiseen voi viedä huomion käsiteltävästä aiheesta. Tällä tavoin esimerkki kiinnittää huomion myös sellaisiin yhteisöllisten tekstikäytänteiden toiminnan haasteisiin, jotka eivät suoranaisesti liity kirjoittamiseen ja tekstin kielelliseen muotoilemiseen. Esimerkissä 6 vuorovaikutuksen ongelmat vaikuttavat liittyvän vuorovaikutuksen osallistujien erilaisiin käsityksiin tekstin tilanteisista käyttötavoista sekä siitä, voidaanko tekstiä työstää prosessimaisesti, jolloin ideointi- ja viimeistelyvaiheet voidaan erottaa toisistaan (vrt. Luukka 2013).

Analyysimme tekstin yhteisestä tuottamisesta mielenterveyskuntoutuksessa viittaa siis vahvaan jännitteeseen yhtältä ohjaajien osallistamispyrkimysten ja toisaalta heidän kuntoutujille faktuaalisesti tarjoamiensa osallistumismahdollisuuksien välillä. Samat tekstin yhteistä omistajuutta ja dokumentointikelpoisuutta koskevat haasteet värittävät kirjoittamista kummassakin ryhmässä. Henkilöstökoulutuksen osallistujat pääsivät niiden yli yhteisöllisiä tekstikäytänteitä taitavasti hyödyntäen, mutta mielenterveyskuntoutuksessa ne näyttäytyvät ylitsepääsemättöminä. Tässä kontekstissa pienryhmäkeskustelujen osallistujilla näyttäisikin olevan nimenomaan yhteisöllisiin tekstikäytänteisiin liittyviä monimuotoisia haasteita, joiden takia vuorovaikutuksessa tapahtuva tekstien yhteinen tuottaminen ei näyttäisi edistävän osallistumista vastaavalla tavalla kuin henkilöstökoulutuksen pienryhmissä.

\section{POHDINTA}

Olemme tässä artikkelissa tarkastelleet tekstin yhteistä tuottamista kahdessa eri kontekstissa: uusiin työkäytänteisiin keskittyvässä henkilöstökoulutuksessa ja työelämään valmentavassa mielenterveyskuntoutuksessa. Molemmissa konteksteissa tekstin yhteinen tuottaminen piti sisällään pyrkimyksiä luoda osallistumismahdollisuuksia ja edistää toimijoista itsestään lähtevää käyttäytymistä (ks. Nivala \& Ryynänen 2013; Siisiäinen 2010).
Kuten analyysimme osoittivat, tekstin yhteinen tuottaminen on kuitenkin vuorovaikutuksellisesti varsin monisyistä ja haasteellista toimintaa, joka vaatii osallistujilta monenlaisia, esimerkiksi tekstin tilanteisiin käyttötapoja, merkitysjärjestelmiä ja viestintäteknologioita koskevia tekstitaitoja. Näin siinä rakentuu jännitteitä osallistamispyrkimysten ja todellisten osallistumismahdollisuuksien välille. Siinä missä osallistumisen tärkeydestä puhutaan paljon ja sitä pyritään edistämään erilaisin yhteiskirjoittamisen keinoin, yhteisöllisiin tekstikäytänteisiin sisältyvien vuorovaikutuksen rakenteiden purkaminen ja näiden tekstikäytänteiden tuottamien osallistumisen mahdollisuuksien ja rajoitusten analysoiminen voikin auttaa ymmärtämään ja arvioimaan yhä paremmin tämänkaltaisten keinojen hedelmällisyyttä.

Henkilöstökoulutuksessa tekstejä tuotetaan koulutettavien pienryhmien kesken osana heille annettua refleksiivistä keskustelutehtävää. Onnistuakseen tämä vaatii osallistujilta monenlaista vuorovaikutuksellista työtä, sillä ryhmän on kyettävä organisoimaan oma kirjoittamistoimintansa ja varmistamaan digitaaliselle alustalle tallennetun kirjauksen yhteisyys. Ryhmän on luotava vuorovaikutukseen jaettu, tehtäväorientoitunut fokus ja valittava kirjuri, jotta tekstin yhteinen tuottaminen pääsee ylipäänsä alkamaan.

Kun tekstiä sitten tuotetaan yhdessä, on osallistujien eriytettävä toiminnallisia roolejaan, jotta he voivat yhteistoimin ja reaaliaikaisesti muotoilla dokumentointikelpoista tekstiä, joka ottaa huomioon koulutuksen ideologian ja toisten ryhmien kirjaukset. Tämä edellyttää sitä, että osallistujat jatkavat toisten lauseita sisällöllisesti ja syntaktisesti sekä pukevat ajatuksiaan kirjalliseen muotoon tavalla, joka ottaa huomioon julkisia kirjauksia koskevat odotustilat ja potentiaaliset ongelmat. Vaikka johtoryhmien näkökulmasta tekstin yhteinen tuottaminen onkin näin varsin haasteellista toimintaa, aineistomme osoittaa, että osallistujat onnistuvat viemään sitä yhteistoimin eteenpäin.

Voidaankin ajatella, että tällainen tekstin tuottamiseen sisältyvien haasteiden yhteinen ratkaiseminen luo erilaisia tilanteisia osallistumispaikkoja, mikä puolestaan parantaa ryhmän jäsenten mahdollisuuksia osallistua yhteisön toimintaan purkaessaan vaikkapa ammatillisiin rooleihin liittyviä valta-asetelmia. 
Tässä mielessä tekstin yhteinen tuottaminen rakentaa vastavuoroisia suhteita ja synnyttää toimintamahdollisuuksia erityisesti johtoryhmän ja sen hallinnoiman koulun sisällä.

Ryhmän toiminnassa voi myös muodostua käytänteitä, jotka kapeuttavat osallistujien toimintamahdollisuuksia. Esimerkiksi kirjurina toimiminen asettaa yhden osallistujan erilaiseen vuorovaikutusasemaan, kun hänen on erityisesti monitoroitava julkisten kirjausten dokumentointikelpoisuutta. Jos kirjuri on aina sama, voi tämä rakentaa pidempiaikaista epäsuhtaa ryhmäläisten osallistumiseen. Lisäksi henkilöstökoulutuksissa osallistumiseen liittyy erityistä kerroksellisuutta - voikin pohtia, miten tekstin yhteinen tuottaminen edistää osallistumista laajemmin työyhteisössä, kun johtoryhmien jäsenet ottavat henkilöstökoulutukseen kuitenkin osaa ylemmän johdon ja ulkopuolisen kouluttajan tekemän suunnitelman velvoittamina, eivät ainoastaan omista lähtökohdistaan käsin (vrt. Siisiäinen 2010) Tästä näkökulmasta tekstin yhteinen tuottaminen voi näyttäytyä - sujuvuudestaan huolimatta - luonteeltaan performatiivisena ja ohuena niin, ettei se saa aikaan esimerkiksi yhteisön käytänteitä tarkastelevaa ja mahdollisesti muuttavaa kriittistä refleksiota vaan pikemmin uusintaa vallitsevia ideologioita ja sitouttaa osallistujia niihin.

Analyysimme tekstin yhteisestä tuottamisesta mielenterveyskuntoutuksen ryhmävuorovaikutustilanteissa nosti esiin muitakin yhteisöllisten tekstikäytänteiden toimintaan kuuluvia haasteita. Kulloisenkin tehtävänannon ja hetki hetkeltä muokkautuvien tehtävien yksityiskohtien seuraaminen osoittautui osallistujille vaikeaksi, mikä näkyi siinä, etteivät kuntoutujien ehdottamat tekstisisällöt aina olleet tarkoituksenmukaisia. Ongelmia aiheutti myös yhteisen ymmärryksen puute siitä, millaisia ehdotuksia voidaan ottaa aidosti käsiteltäviksi. Lisäksi kuntoutujien kielelliset valmiudet eivät aina näyttäneet riittävän toisen aloittaman kielellisen rakenteen täydentämiseen. Ohjaajat suuntautuivat monimuotoisiin haasteisiin kohtelemalla kuntoutujien ehdotuksia riittämättöminä. He eivät kuitenkaan selittäneet, mikä niissä oli ongelmallista. Toisin kuin tällaisissa tilanteissa voisi ajatella muissa konteksteissa toimittavan, he eivät käsitelleet kuntoutujien ehdotusten puutetta vastarintana tai pyytäneet heiltä ehdotuksilleen perusteita. Kuntoutujien kielellisten valmiuksien puutetta tekstitaidoissa ei myöskään nostettu tilanteen kannalta tarkoituksenmukaisiksi harjoiteltaviksi asioiksi. Sen sijaan ohjaajat ohittivat ryhmäläisten ehdotusten puutteet sen laatuisina ongelmina, joita ei ole soveliasta tai tarpeellista nostaa vuorovaikutuksen pintatasolle. Tavanomainen ongelmien selvittäminen ei ikään kuin ollut edes vaihtoehto.

On ymmärrettävää, että mielenterveyskuntoutuksen kontekstissa ohjaajat etsivät keinoja vuorovaikutuksen sujuvoittamiseksi tavoilla, jotka kuitenkin rakentaisivat osallistumisen mahdollisuuksia ryhmäläisille. Valmiiden tekstipohjien käyttäminen vaikuttaa perustellulta ratkaisulta, sillä sen myötä monet edellä mainituista tekstin yhteisen tuottamisen ongelmista ratkeavat helposti. Samalla tekstin tekniseen uudelleen kirjoittamiseen osallistumisen voi ajatella toimivan mahdollisuutena ryhmäläisten "osittaiseen osallistumiseen" (peripheral participation; Lave \& Wenger 1991).

Tämä nostaa kuitenkin esiin kysymyksen siitä, onko vuorovaikutuksen näennäinen sujuvuus arvo sinänsä, jos sen hintana on valmiin tekstin kopioimisen sisällään pitämä mahdottomuus tuottaa tekstin sisältöön juuri mitään sisällöllistä, mikä tarkoittaa vääjäämättä vähäisempää osallistumista. Mielenterveyskuntoutujien osallistumisella tekstin yhteiseen tuottamiseen on kuitenkin nähtävissä myös suoremmin kirjoittamiseen ja tekstitaitoihin liittyviä perusteita. Työvalmennusryhmän tavoitteena on parantaa kuntoutujien työelämätaitoja, joista kyky tuottaa tekstiä oikein on yksi perustava työelämän vaatimus. Kun kirjoittamista ohjataan ryhmän päätöksentekotilanteessa, demokraattisen osallistumisen päätoiminnon "sivutuotteena", se näyttäytyy kasvoja vähemmän uhkaavana toimintana kuin julkilausutusti opettamisorientoitunut toiminta (vrt. Wiklund \& Stevanovic 2018) - ovathan osallistujat aikuisia, joiden periaatteessa tulisi osata kirjoittaa oikein.

Kuten kaikkien keskustelunanalyyttisten tutkimusten, tämän tutkimuksen tulokset pohjautuvat suhteellisen pieneen märään vuorovaikutusaineistoa. Niiden pohjalta voidaan silti lisätä kokonais- 


\section{DOKUMENTOINTIKELPOISUUS}

\section{VÄISTÄMÄTT ̈̈}

\author{
ASETTAA RAJOITUKSIA
}

KIRJOITTAMISELLE

\section{OSALLISTUMISEN MUOTONA.}

valtaista ymmärrystä siitä, millaiset käytänteet ja vuorovaikutusilmiöt - tässä tapauksessa tekstin yhteistä tuottamista koskevat, osallistumista koskevat jännitteet - ovat ylipäätään mahdollisia ihmisten välisessä toiminnassa (Peräkylä 2011, 375-376). Tulostemme luotettavuuden lisäämiseksi olemme analysoineet aineistoa keskustelunanalyyttisen tutkimusperinteen mukaisesti tutkijoiden yhteisissä niin sanotuissa datasessioissa (ks. Stevanovic \& Weiste 2017) ja esittäneet analyysimme tuloksia tieteellisissä konferensseissa. Keskustelunanalyysin keskeinen metodologinen työkalu on periaate tulkita vuorovaikutusaineistoa osallistujalähtöisesti: jokainen vuoro täytyy tulkita sen perusteella, miten vastaanottaja sen seuraavassa vuorossa tulkitsee (next-turn proof procedure, Sacks ym. 1974, 729). Näin vuorovaikutuksen osallistujien omaa orientaatiota tulkitseva analyysimme on jokaisen tämän artikkelin aineistoesimerkkejä lukevan saatavilla ja tarkistettavissa.

Keskustelunanalyyttinen tapaustutkimuksemme nosti esiin useita käytännön ohjaus- ja opetustyön kannalta tärkeitä seikkoja. Yhteisöllisten tekstikäytänteiden hallinta ei kuitenkaan synny pelkästä kirjoitusmahdollisuuden tarjoamisesta, vaan sitä on tuettava erilaisin pedagogisin ratkaisuin. Mielenterveyskuntoutuksen työvalmennuskonteksteissa yksi hedelmällinen keino voisi olla tekstin yhteisen tuottamisen aiempaa selkeämpi nostaminen harjoiteltavaksi työelämätaidoksi. Tekstualisoituneessa tieto- ja merkitysyhteiskunnassa työelämätaidot ovat olennaisesti juuri erilaisten tekstien välityksellä tapahtuvan informaation käsittelyä, mikä ei pelkisty pelkäksi oikeinkirjoitukseksi. Tekstitaitotutkimuksessa on viime vuosina puhuttu yhtäältä uusista luku- ja kirjoitustaidoista tulevaisuuden avaintai- toina ja toisaalta osattomuudesta, joka syntyy, ellei pääse itse aktiivisesti osallistumaan erilaisten tietosisältöjen tuotantoon ja sitä myötä yhteisöllisiin ja yhteiskunnallisiin prosesseihin, vaan jää ainoastaan toisten tuottaman tiedon vastaanottajaksi (esim. Kallionpää 2017).

Osallistumisen tukemisen näkökulmasta yksi ratkaisu on, että ohjaajat ottaisivat nykyistä useammin julkilausutusti päävastuun tekstin kielellisestä muokkaamisesta tai siirtäisivät muokkaamisen toiseen tilanteeseen. Keskeistä tässä olisi kirjoittamistoiminnan yhä selkeämpi strukturointi ja työskentelyn prosessimaisen luonteen selittäminen jo prosessin alkumetreillä (ks. Jyrkiäinen \& Koskinen-Sinisalo 2015). Tällöin vuorovaikutustilanteessa tekstin sisällöistä neuvotteleminen voisi olla keskeisemmässä osassa kuntoutujien toimintaa, jolloin se - toimijuuden ja aidon osallistumisen ideaalin mukaisesti (Siisiäinen 2010) - kohdistuisi vielä todennäköisemmin kuntoutujille itselleen merkityksellisiin asioihin. Ensisijaista olisivat siis aito osallistuminen ja yhteisöllisyys, joita tuettaisiin yhdessä kirjoittamisen toimivuutta edistävin pedagogisin ratkaisuin.

Kun taas pohditaan yhdessä kirjoittamista pedagogisena ratkaisuna, 'dokumentointikelpoisuuden' käsitteen hyödyntäminen ja avaaminen sekä pohtiminen osallistujien kanssa voisi olla hedelmällistä. Käsite viittaa paitsi siihen, että kirjoitetun tekstin odotetaan olevan yleiskielen käytänteiden mukaista, myös siihen, että tekstit tuotetaan aina johonkin tarkoitukseen, jolloin niiden tuottamista ohjaavat erilaiset normit ja odotukset. Dokumentointikelpoisuuden vaatimus siten väistämättä asettaa rajoituksia kirjoittamiselle osallistumisen muotona: kaikki ehdotetut kontribuutiot eivät mitenkään voi olla relevantteja tekeillä olevan tekstin käyttötarkoituksen näkökulmasta. Yhteinen tekstin tuottaminen ei toisin sanoen aina näyttäydy toimivana keinona edistää tasavertaista osallistumista ja yhteisöllisen päätöksenteon ihanteita.

Yhteisölliset tekstikäytänteet voidaan kuitenkin ymmärtää myös laajemmin, jolloin tekstitaitojen edistäminen koskee lisääntyvää ymmärrystä osallistumisen mahdollisuuksista ja rajoitteista kussakin tilanteessa. Tätä kautta tutkimuksemme liittyy 
myös aiempaan kasvatustieteelliseen tutkimukseen, jossa huomion kohteena ovat käytännön opetustyössä keskeiset ja toistuvat aktiviteetit ja käytänteet (Forzani 2014; Karvonen 2019). Suomessa tekstitaitoja on tästä näkökulmasta lähestynyt Ulla Karvonen (2019), joka tutkii perusopetuksen toteutuvaa opetussuunnitelmaa eli niitä oppimisen mahdollistavia tilanteita ja kokemuksia, jotka syntyvät opettajan ja oppilaiden toimiessa opetustilanteessa oppimateriaalien - tekstiartefaktien - ympärillä.

Kuten Karvonen (2019) osoittaa, tekstien käyttömahdollisuudet rakentuvat tilanteisesti osallistujien vuorovaikutuksessa tekemien valintojen kautta. $\mathrm{Ne}$ ovat kuitenkin ennen muuta sidoksissa opettajan ammatilliseen taitoon tunnistaa tekstien pedagogisia mahdollisuuksia ja hyödyntää niitä refleksiivisesti osana vuorovaikutusta. Toistaiseksi tämänkaltaista

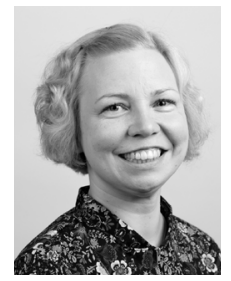

MELISA STEVANOVIC

VTT, yliopistonlehtori

yhteiskuntatutkimuksen yksikkö

Tampereen yliopisto

(D) https://orcid.org/0000-00020429-1672

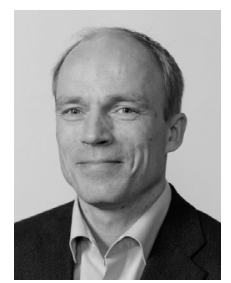

\section{ESA LEHTINEN}

$\mathrm{FT}$, nykysuomen professori kieli- ja viestintätieteiden laitos Jyväskylän yliopisto

(D) https://orcid.org/0000-00030218-6075

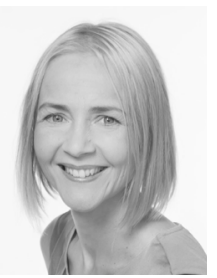

\section{CAMILLA LINDHOLM}

FT, pohjoismaisten kielten professori

Tampereen yliopisto

(D) https://orcid.org/0000-00019220-5414 tutkimusta on kuitenkin tehty niukasti aikuiskoulutuksen konteksteissa, eritoten aineistomme kaltaisissa yrityksissä ja järjestöissä, joista viralliset opetussuunnitelmat pedagogisine periaatteineen puuttuvat.

Tutkimuksemme tekeekin näkyväksi niitä vuorovaikutuksellisia tapoja, joilla yhteisöllisiä tekstikäytänteitä rakennetaan ja hyödynnetään tällaisissa pedagogisilta kehyksiltään epämääräisemmissä oppimistilanteissa, joissa oppimista tuetaan ja osallistumiseen ohjataan epäsuorasti asteittain syvenevän osallistumisen kautta (Lave \& Wenger 1991). Yhteisöllisten tekstitaitojen edistämisen voidaan tällöin ajatella lisäävän samalla metatason ymmärrystä osallistumisen mahdollisuuksista ja rajoitteista. Osallistuminen ja tekstitaidot ovatkin osa samaa haastetta, johon toimivat aikuiskasvatuksen pedagogiset käytännöt voivat tarjota ratkaisuja.

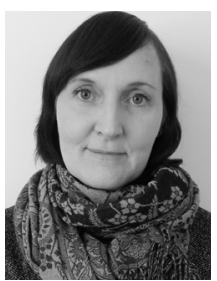

RIIKKA NISSI

FT, soveltavan kielitieteen yliopistonlehtori kieli- ja viestintätieteiden laitos Jyväskylän yliopisto

(iD https://orcid.org/0000-00027083-070X

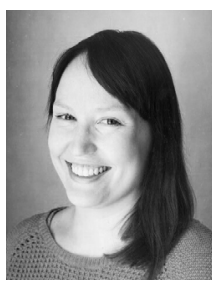

\section{TAINA VALKEAPÄÄ}

VTM, projektikoordinaattori Helsingin yliopisto

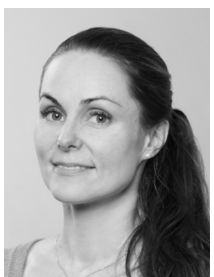

\section{ELINA WEISTE}

VTT, tutkijatohtori Helsingin yliopisto

(D) https://orcid.org/0000-00026879-6004 


\section{LIITE 1}

\section{Litterointimerkit (Stevanovic \& Lindholm 2016)}

$\begin{array}{ll}\text { [ ] } & \text { päällekkäispuhunta } \\ \text { (. ) } & 0.2 \text { sekuntia lyhyempi hiljaisuus } \\ \text { (0.6) } & \text { hiljaisuus, mitattuna sekunteina } \\ = & \text { kaksi lausumaa liitetty toisiinsa tauotta } \\ \text {. hh } & \text { äänekäs sisäänhengitys } \\ \text { hh } & \text { äänekäs uloshengitys } \\ \uparrow & \text { nuolen jälkeinen sana tai tavu lausuttu } \\ & \text { ympäröivää puhetta korkeammalta } \\ \text {, } & \text { tasainen sävelkulku } \\ \text {. } & \text { laskeva sävelkulku }\end{array}$

$\begin{array}{ll}\text { ? } & \text { nouseva sävelkulku } \\ \text { sana } & \text { äänteen tai tavun painottaminen } \\ \text { sa:na } & \text { edeltävän äänteen venyttäminen } \\ \text { sa- } & \text { sana jää kesken } \\ { }^{\circ} \text { sana }{ }^{\circ} & \text { ympäröivää puhetta hiljaisemmalla äänellä } \\ & \text { puhuttu jakso } \\ \text { @sana@ } & \text { äänensävyn muuntyyppinen muutos } \\ (-) & \text { sana, josta ei saatu selvää } \\ ((\operatorname{sana})) & \text { litteroijan selityksiä }\end{array}$

\section{LÄHTEET}

Asmuss, B. \& Oshima, S. (2012). Negotiation of entitlement in proposal sequences. Discourse Studies 14(1), 67-86.

Barton, D. (1994). Literacy: An introduction to the Ecology of Written Language. Oxford: Blackwell.

Barton, D. \& Hamilton, M. (2000): Literacy practices. Teoksessa Barton D., Hamilton M. \& Ivanic R. (toim.), Situated literacies: Reading and writing in context. London: Routledge, 7-15.

Bourdieu, P. (1977). Outline of a theory of practice. New York: Cambridge

University Press.

Brodie, E., Cowling, E., Nissen, N., Paine, A. E., Jochum, V., \& Warburton, D. (2009). Understanding participation: A literature review. National Council for Voluntary Organisations. http://www.sp.gov.tr/ upload/Sayfa/47/files/Pathways-literature-reviewfinal-version.pdf.

Corrigan P.W., Faber, D., Rashid, F, and Leary, M. (1999). The construct validity of empowerment among consumers of mental health services. Schizophrenia Research 38(1), 77-84.

Dobao, A. F. (2012). Collaborative writing tasks in the L2 classroom: Comparing group, pair, and individual work. Journal of Second Language Writing 21(1), 40-58.

Forzani, F.M. (2014). Understanding "core practices" and "practice-based" teacher education: Learning from the past. Journal of Teacher Education 65(4), 357-368.

Gee, J. (2015). Social linguistics and literacies: Ideology in discourses. London: Taylor \& Francis.

Heritage, J. (1996). Harold Garfinkel ja etnometodologia. Jyväskylä: Gaudeamus.
Hibbard, J. H. \& Greene, J. (2013). What the evidence shows about patient activation: Better health outcomes and care experiences; fewer data on costs. Health Affairs 32(2), 207-214.

Hyytiäinen, J. (2017). Anvisningar och uppmaningar i klassrumsinteraktion: Lärarens direktiv $i$ svenskundervisningen i finska skolor. Väitöskirja. Helsingin yliopisto.

Jenkins, H., Ito, M. \& Boyd, D. (2016). Participatory culture in a networked era: A conversation on youth, learning, commerce and politics. Cambridge: Polity Press.

Jyrkiäinen, A. \& Koskinen-Sinisalo, K.-L. (2015). Yhteisöllinen tekstintuottaminen kuuluu monilukutaitoon - yhdessä tekemisen pedagogiikkaa etsimässä. Teoksessa T. Kaartinen (toim.), Monilukutaito kaikki kaikessa. Tampere: Tampereen yliopistopaino, 77-98.

Kallionpää, O. (2017). Uuden kirjoittamisen opetus: Osallistavaa luovuutta verkossa. Väitöskirja. Jyväskylän yliopisto.

Karvonen, U. (2019). Tekstit luokkahuonevuorovaikutuksessa. Oppimateriaalit toteutuvan opetussuunnitelman rakentamisessa. Väitöskirja. Helsingin yliopisto.

Komter, M. (2006). From talk to text: The interactional construction of a police record. Research on Language and Social Interaction 39(3), 201-228.

Lave, J. \& Wenger, E. (1991). Situated learning: Legitimate peripheral participation. Cambridge: Cambridge University Press.

Lehti, L., Peltonen, P., Routarinne, S. Vaakanainen, V. \& Virsu, V. (2018). Uusia lukutaitoja rakentamassa: Lukutaidon moninaiset merkitykset ja tutkimusmenetelmät. Teoksessa L. Lehti, P. Peltonen, S. Routarinne, V. Vaakanainen \& V. Virsu (toim.) 
Uusia lukutaitoja rakentamassa. Jyväskylä: Suomen soveltavan kielitieteen yhdistys AfinLA, 6-21.

Limbu, L. \& Markauskaite, L. (2015). How do learners experience joint writing: University students' conceptions of online collaborative writing tasks and environments. Computers \& Education 82, 393-408.

Luukka, M.-R. (2009). Tekstitaidot - teksteistä käytänteisiin. Teoksessa M. Harmanen \& T. Takala (toim.) Tekstien pyörityksessä - tekstitaitoja alakoulusta yliopistoon. Helsinki: Äidinkielen opettajain liitto, 13-25.

Luukka, M.-R. (2013). Opetussuunnitelmat uudistuvat: Tekstien lukijasta ja kirjoittajasta monilukutaituriksi. Kieli, koulutus ja yhteiskunta 4(5). http://www. kieliverkosto.fi/article/opetussuunnitelmat-uudistuvattekstien-lukijasta-ja-kirjoittajasta-monilukutaituriksi.

Mondada, L. (2016). Going to write: Embodied trajectories of writing of collective proposals in grassroots democracy meetings. Language and Dialogue 6(1), 140-178.

Mondada, L. \& Svinhufvud, K. (2016). Writing-ininteraction: Studying writing as a multimodal phenomenon in social interaction. Language and Dialogue 6(1), 1-53.

Moore, R.J., Whalen, J. \& Gathman, C.H. (2010). The work of the work order: Document practice in faceto-face service encounters. Teoksessa N. Llewellyn \& J. Hindmarsh (toim.), Organisation, interaction and practice: Studies in ethnomethodology and conversation analysis. Cambridge: Cambridge University Press, 172-197.

Neumann, H. \& McDonough, K. (2015). Exploring student interaction during collaborative prewriting discussions and its relationship to L2 writing. Journal of Second Language Writing 27, 84-104.

Nissi, R. (2015). From entry proposals to a joint statement: Practices of shared text production in multiparty meeting interaction. Journal of Pragmatics 79, 1-21.

Nivala, E. \& Ryynänen, S. (2013). Kohti sosiaalipedagogista osallisuuden ideaalia. Sosiaalipedagoginen aikakauskirja 14, 9-41.

NLG = The New London Group 1996. A pedagogy of multiliteracies: Designing social futures. Harvard Educational Review 66(1), 60-93.

Pahkin, K., Mattila-Holappa, P., Nielsen, K., WiderszalBazyl, M., \& Wiezer, N. (2014). A sound change: Ways to support employees' well-being during organizational restructuring. Teoksessa S. Leka, S. \& R. R. Sinclair (toim.) Contemporary Occupational Health Psychology: Global Perspectives on Research and Practice. Chichester: Wiley-Blackwell, 165-180.

Peräkylä, A. (2011). Validity in research on naturally occurring social interaction. Teoksessa Silverman D. (toim.) Qualitative research. Third edition. London: Sage.
Planes-Satorra, S. \& Paunov, C. (2017), Inclusive innovation policies: Lessons from international case studies. OECD Science, Technology and Industry Working Papers 2017/02. Paris: OECD Publishing.

Pälli, P. \& Lehtinen, E. (2014). Making objectives common in performance appraisal interviews. Language and Communication 39, 92-108.

Pälli, P., Vaara, E. \& Sorsa, V. (2009). Strategy as text and discursive practice: A genre-based approach to strategizing in city administration. Discourse and Communication 3(3), 303-318.

Sacks, H., Schegloff, E. \& Jefferson, G. (1974). A simplest systematics for the organization of turn taking in conversation. Language 50, 696-735.

Samra-Fredericks, D. (2010). The interactional accomplishment of a strategic plan. Teoksessa N. Llewellyn \& J. Hindmarsh (toim.), Organisation, interaction and practice: Studies in ethnomethodology and conversation analysis. Cambridge: Cambridge University Press, 198-217.

Schegloff, E.A. (2007). Sequence organization in interaction: A primer in conversation analysis. Cambridge: Cambridge University Press.

Siisiäinen, Martti (2010). Osallistumisen ongelma. Kansalaisyhteiskunta 1(1), 8-40.

Stevanovic, Melisa (2017). Managing compliance in violin instruction: The case of the Finnish clitic particles $-p A$ and $-p A s$ in imperatives and hortatives. Teoksessa M.L. Sorjonen, L. Raevaara \& E. Couper-Kuhlen (toim.) Imperative Turns at Talk: The design of directives in action. Amsterdam: Benjamins, 357-380.

Stevanovic, M. \& Lindholm, C. (toim.) (2016). Keskustelunanalyysi: Kuinka tutkia sosiaalista toimintaa ja vuorovaikutusta. Tampere: Vastapaino.

Stevanovic, M. \& Weiste, E. Conversation-analytic datasession as a pedagogical institution. Learning, Culture and Social Interaction 15, 1-17.

Storch, N. (2005). Collaborative writing: Product, process, and students' reflections. Journal of Second Language Writing 14(3), 153-173.

Svinhufvud, K. (2016). Nodding and note-taking: Multimodal analysis of writing and nodding in student counseling interaction. Language and Dialogue 6(1), 81-109.

Van Charldorp, T.C. (2014). "What happened?" From talk to text in police interrogations. Language and Communication 36, 7-24.

Wigglesworth, G. \& Storch, N. (2012). What role for collaboration in writing and writing feedback. Journal of Second Language Writing 21(4), 364-374.

Wiklund, M. \& Stevanovic, M. (2018). Ymmärrysongelmat ja vuorovaikutustaitojen opettaminen lievästi autististen varhaisnuorten kuntoutuskeskusteluissa. Psykologia 53(5-6), 421-439. 